1 Remote Sensing for Drought Monitoring \& Impact Assessment: Progress, Past

2 Challenges and Future Opportunities

3

$4 \quad$ Harry West, Nevil Quinn \& Michael Horswell

5 Centre for Water, Communities \& Resilience; Department of Geography \& Environmental

6 Management; University of the West of England, Bristol

7

8 Corresponding Author: Harry West (harry.west@uwe.ac.uk)

9

10

11

12

13

14

15

16

17

18

19

20

21

22

23 


\section{Challenges and Future Opportunities}

Abstract

Drought is a common hydrometeorological phenomenon and a pervasive global hazard. As our climate changes, it is likely that drought events will become more intense and frequent. Effective drought monitoring is therefore critical, both to the research community in developing an understanding of drought, and to those responsible for drought management and mitigation. Over the past 50 years remote sensing has shifted the field away from reliance on traditional site-based measurements and enabled observations and estimates of key drought-related variables over larger spatial and temporal scales than was previously possible. This has proven especially important in data poor regions with limited in-situ monitoring stations. Available remotely sensed data products now represent almost all aspects of drought propagation and have contributed to our understanding of the phenomena. In this review we chart the rise of remote sensing for drought monitoring, examining key milestones and technologies for assessing meteorological, agricultural and hydrological drought events. We reflect on challenges the research community has faced to date, such as limitations associated with data record length and spatial, temporal and spectral resolution. This review then looks ahead to the future in terms of new technologies, such as the ESA Sentinel satellites, analytical platforms and approaches, such as Google EarthEngine, and the utility of existing data in new drought monitoring applications. We look forward to the continuation of 50 years of progress to provide effective, innovative and efficient drought monitoring solutions utilising remote sensing technology. 


\section{Keywords}

Drought; Drought Monitoring; Meteorological Drought; Agricultural Drought; Hydrological

Drought; Remote Sensing of Drought; Review Paper.

51

\subsection{Introduction}

53

Drought is a common hydrometeorological phenomenon (Hayes et al., 2012), and a

pervasive hazard, second only to flooding in its impact on social and economic security

(Nagarajan, 2009). Since the turn of the century, several socio-economically significant

regional droughts have occurred, for example in Australia (2000-2009), USA (2000-2016),

Southern and Sub-Saharan Africa (2015-2017), China (2007-2012) and Europe (2007-2010)

(Ummenhofer et al., 2009; Ault et al., 2016; Chao et al., 2016; Cook et al., 2016; Baudoin et

al., 2017). There is no universal definition of a drought (Lloyd-Hughes, 2014), but in its simplest form a drought event represents a deficit of water relative to normal conditions. Unlike floods which have a clear and sudden start and end (Wang et al., 2016), droughts can be characterised by slow development and prolonged impacts. How spatio-temporally variable rainfall deficits propagate through the land surface to register deficits in soil moisture, runoff and recharge is complex and heterogeneous. While droughts can be ended by sudden extreme precipitation, how to precisely identify the termination point of a drought event is contested (Parry et al., 2016). These attributes mean that drought is a phenomenon that is challenging to quantify and analyse. Impacts from recent droughts reveal high levels of exposure and vulnerability of both natural and human systems (Van Loon et al., 2016). This is significant as with future climate change it is likely that many areas will start to experience more frequent and intense dry conditions, with irreversible impacts 
71 for people and ecosystems (IPCC, 2014). Consequently, drought monitoring and mitigation

72 have become urgent scientific issues (Liu et al., 2016).

74 Historically drought monitoring approaches have focused on in-situ station-based measurements, for example the Palmer Drought Severity Index (PDSI) (Palmer, 1965). Towards the end of the $20^{\text {th }}$ century a paradigm shift in drought monitoring approaches occurred, concurrent with advances in remote sensing and earth observation technologies such as the launch of the NASA Landsat series in 1972. In addition to providing meteorological data, remote sensing-based approaches also monitor conditions at the Earth's surface such as vegetation health and water levels, providing a rich mix of contextual data for drought monitoring. Remote sensing has consequently revolutionised the field, allowing observations and monitoring of key drought-related variables over larger temporal and spatial scales than was previously possible using conventional methods (Choi et al., 2013; Sur et al., 2015). The role of remote sensing technologies for effective water management has been highlighted as of particular importance in developing 'data-poor regions' (Sheffield et al., 2018).

This paradigm shift in drought monitoring approaches is marked in the number of droughtrelated papers appearing in Remote Sensing of Environment; from less than 5 per year in 1982, to more than 70 per year since 2014 (Figure 1). Other journals (e.g. Remote Sensing, International Journal of Applied Earth Observation and Geoinformation and International Journal of Remote Sensing), have also seen a significant increase, and this is the case in hydrology and water management research journals too (Lettenmaier et al., 2015). 


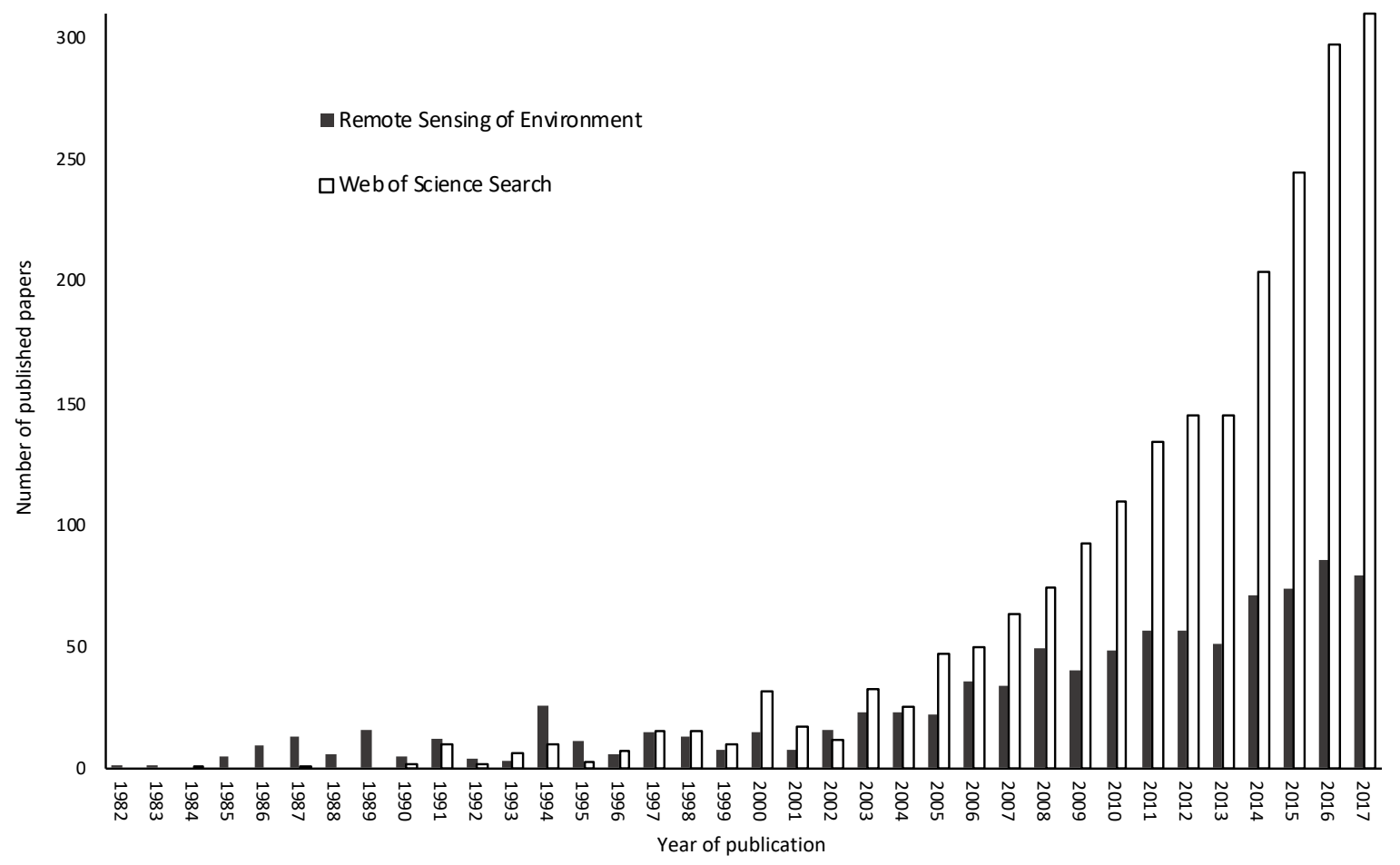

95

96 Figure 1: Number of papers relating to drought (in both paper titles and keywords) in

97 Remote Sensing of Environment and Web of Science since 1982. Search terms included

98 various versions of 'Drought' and 'Remote Sensing'.

99

100 Although droughts are complex phenomena which propagate in different ways with varied

101 characteristics, they are commonly classified into one of four types, namely meteorological drought, agricultural drought, and hydrological drought (which represent the

103 natural/environmental impacts), and socio-economic drought (which represents the impact 104 on human population and society) (Van Loon, 2015; Liu et al., 2016). These types are not 105 independent but refer to different approaches of measurement and identification (Wilhite 106 \& Glantz, 1985) (Figure 2). 




108 Figure 2: Different types of drought, their interactions and associated impacts (Adapted

109 from Van Loon, 2015)

110

111 Drought propagation is the process whereby a precipitation deficit (i.e. below average

112 rainfall) progresses through the hydrological cycle, starting with meteorological drought and

113 developing into hydrological drought if conditions persist (Van Loon, 2015). Factors

114 influencing the nature of drought propagation include regional climate and local catchment

115 characteristics, such as geology, vegetation cover and type, soils, topography and human

116 influence (Van Loon \& Laaha, 2015; Baker et al., 2016). Given the complex characteristics of

117 drought, event heterogeneity, and various propagation pathways and influences, remote

118 sensing can provide a valuable tool in the monitoring of a range of drought-related

119 variables.

121 This review will focus on the remote sensing-based monitoring of 'environmental drought',

122 that is events that can be classified as being either meteorological, agricultural or

123 hydrological drought and the relationships between them. Since the start of remote sensing 
124

125

126

127

128

129

130

131

132

133

134

135

136

137

138

139

140

141

142

143

144

145

146

147

application in the field of drought monitoring active and passive sensors, recording measurements across the electromagnetic spectrum, have been used to improve understanding and inform environmental management decisions. Recent years have seen rapid evolution in remote sensing technologies which can be applied in drought monitoring, such as the launch of the ESA Sentinel satellites and the development of new indicators and analytical platforms. Given the rate of technological evolution it is important to continuously review and reflect upon historic and recent developments and look ahead to new opportunities.

\subsection{Precipitation Monitoring}

Meteorological drought typically results from the presence of continuously high atmospheric pressure over a region, representing a significant negative deviation from mean precipitation (Sheffield \& Wood, 2011). Meteorological droughts tend to occur over relatively short time scales, usually days/weeks but possibly extending into months/seasons (Pal et al., 2000), and the associated precipitation deficit is the propagation trigger for agricultural and hydrological drought. Unlike the other drought types, a meteorological drought will typically have few direct impacts (Sen, 2015). Nonetheless, given meteorological drought is often an early indicator of more impactful and significant dry events, effective monitoring is still critical.

Historically, site-based precipitation measurements were essential for meteorological drought monitoring, but the introduction of remote sensing precipitation products changed the efficiency and spatio-temporal coverage of rainfall mapping and drought monitoring (e.g. Islam \& Uyeda, 2005; Islam \& Uyda, 2007; Almazroui, 2011; Du et al., 2013; Zhang et 
al., 2017a). The first of these was the TRMM (Tropical Rainfall Measuring Mission), a joint collaboration between NASA and the Japan Aerospace Exploration Agency (JAXA). Launched in 1997 and decommissioned in 2015, TRMM measured tropical and subtropical rainfall $\left(35^{\circ} \mathrm{S}-35^{\circ} \mathrm{N}\right)$ and was the first satellite to carry a specific microwave precipitation radar

152 (Kummerow et al., 1998). Due to its restricted orbital cycle TRMM completed 16 cycles per day, with a measurement swath of $878 \mathrm{~km}$ and spatial resolution of 0.25 degrees at the time of decommissioning. The 17-year legacy dataset represents a significant benchmark in global rainfall measurement and is still routinely used in assessing global rainfall patterns and atmospheric drivers of drought (e.g. Zhang \& Jia, 2013; Sahoo et al., 2015; Forootan et al., 2016; Yan et al., 2018). The successor to TRMM is the Global Precipitation Measurement (GPM) mission (Hou et al., 2014). The GPM Core Observatory was launched in February 2014. This also operates in a non-polar, low inclination orbit completing 16 cycles per day, however with a wider coverage than TRMM $\left(65^{\circ} \mathrm{S}-65^{\circ} \mathrm{N}\right)$. Along with a constellation of other satellites this gives a revisit time for GPM products of 1-2 hours, with an improved spatial resolution (0.1-0.25 degrees). Studies have assessed the accuracy of GPM retrievals at various scales through correlation with in-situ gauged data and TRMM data (Tang et al., 2016; Libertino et al., 2016; Caracciolo et al., 2018), with results suggesting high levels of agreement. Consequently, GPM and coupled TRMM/GPM datasets have become important products in drought monitoring research (e.g. Zhang et al., 2017b; Alizadeh \& Nikoo, 2018).

Studies have used a range of analytical approaches when employing remotely sensed precipitation in drought monitoring, including the calculation of long-term rainfall anomalies

171 Precipitation Condition Index (PCI) (Zhang et al., 2017a). One of the most commonly used 
indices that can be derived from remote sensing data is the Standardised Precipitation Index

173 (SPI). Developed by McKee et al. (1993), the SPI is calculated using precipitation alone,

174 which meant at the time it was far more data efficient than the PDSI for many applications.

175 The main advantage of the SPI is that the values have the same probability of occurrence,

176 no matter the time period, location, or scale, and equally represent both flood/wet and

177 drought/dry events along a continuum. Until recently, its use has been limited in remote

178 sensing studies, due to the need for a long-term precipitation record for calculation

179 (traditionally $\sim 30$ years). However, with long-term records now becoming available it is

180 possible to calculate SPI using remotely sensed data alone, enabling detection of

181 meteorological droughts over large spatial scales (e.g. Sahoo et al., 2015; Winkler et al., 182 2017; Elhang \& Zhang, 2018; Zhao et al., 2018).

\subsection{Evapotranspiration Monitoring}

As discussed above, the onset of meteorological drought is often a key predictor of agricultural/hydrological drought. Consequently, it is common for research to attempt to integrate meteorological drought-related variables into studies which aim to assess and improve the monitoring of these other drought types. A key factor of both meteorological and agricultural drought is the increase in evapotranspiration rates (Figure 2). Reliable estimation of evapotranspiration is essential for effective drought monitoring and the development of hydrologic models (Fisher et al., 2017). As with precipitation, a key benefit of using remotely sensed products is the ability to assess evaporation/evapotranspiration over large areas, and in the absence of in-situ monitoring stations. Calculation of evaporation/evapotranspiration requires additional variables relating to vegetation 
estimated through remote sensing. As such, various evapotranspiration remote sensing data products now exist - derived from observations from a range of satellite families, such as the MODIS and Landsat satellites.

The Global Land Evaporation Amsterdam Model (GLEAM) (Miralles et al., 2011) is a set of algorithms for estimating terrestrial evaporation and soil moisture. The approach was revised in 2014 (Miralles et al., 2014) and is currently on its third iteration (Martens et al., 2017). The current GLEAM product consists of a series of microwave (C- and L-band) measurements of vegetation, soil moisture and precipitation and thermal observations of land surface temperature (LST), from sensors such as MODIS (Moderate Resolution Imaging Spectroradiometer) and the SMOS (Soil Moisture Ocean Salinity) mission (Martens et al., 2017). The uniqueness of GLEAM is that it is the only global scale evaporation product designed to be driven by remotely sensed data alone (Miralles et al., 2011). Given that GLEAM uses data from sensors which have a long operational history, Version 3.3 of the product is available for the period 1980-2018.

Many drought-related studies using remotely sensed precipitation or evapotranspiration products have been at global or continental scales (Sahoo et al., 2015; Xia et al., 2018), and necessarily at coarse spatial resolution (Huffman et al., 1997; Martens et al., 2017). This may be because many of the earlier earth observation satellites prioritised temporal over spatial resolution (Lettenmaier et al., 2015). However, attempts have recently been made to increase the spatial resolution of meteorological remotely sensed data. For example, van Dijk et al. (2018) used MODIS observations of surface water extent, vegetation, and LST, assimilated into a landscape hydrological model, to derive a $5 \mathrm{~km}$ resolution global scale 
dataset of secondary evaporation (i.e. evaporation from floodplain/wetland storage and

221 irrigation systems).

222

223

Passive sensor derived datasets have also been re-analysed to represent evaporation/evapotranspiration. For example, the Landsat satellites have been used in the development of new, higher resolution, monitoring approaches (Wulder et al., 2019). With the addition of the thermal band on Landsat 3 (launched in 1978), which was later enhanced on Landsat 4 (1982) onwards, high resolution (30m visible and $120 \mathrm{~m}$ thermal) retrievals of land classifications and LST were made possible. These observations have led to the retrieval of relatively high-resolution estimates of evapotranspiration (Vinukollu et al., 2011). Recent work has been undertaken using the Google EarthEngine (Gorelick et al., 2017) to calculate key meteorological/hydrological variables using the thermal capabilities of space-borne sensors. EEFlux (EarthEngine Evapotranspiration Flux) was developed based on the METRIC (Mapping Evapotranspiration at High Resolution with Internalized Calibration) model (Allen et al., 2007) and applies a series of algorithms to produce evapotranspiration estimates using Landsat 5 TM (1984-2013), Landsat 7 ETM+ (1999-Present) and Landsat 8 OLI-TIRS (2013-Present) imagery.

\subsection{Vegetation \& Soil Moisture Monitoring}

Sustained meteorological drought over a region will begin to impact upon local hydrology and agriculture (Dutra et al, 2014). Agricultural drought (also referred to as soil moisture drought) represents a deficit in soil moisture available to vegetation driven by a precipitation deficit (meteorological drought) (Liu et al., 2016). Agricultural droughts tend to 
occur over medium to long term time scales and associated impacts include crop yield

244 reductions or failure, and eventually food demand/supply disequilibrium.

Remotely sensed agricultural drought monitoring can be via measurement of soil moisture content, usually through microwave radar (active) and radiometers (passive) such as SMOS or SMAP (Soil Moisture Active Passive) (e.g. Martínez-Fernández et al., 2016; Mishra et al., 2017; Rajasekaran et al., 2018), or through the assessment of vegetation using passive multispectral sensors such as Landsat or more recently Sentinel-2/-3 (e.g. Gu et al., 2008: Zhang et al., 2017a; Myoung-Jin et al., 2018). The former represents a direct measurement of soil moisture, while the latter infer this by assessing vegetation condition or productivity.

\subsection{Passive Multispectral Remote Sensing Approaches} In the late $20^{\text {th }}$ and early $21^{\text {st }}$ century various multispectral indices, applicable in drought monitoring, were developed. These include the Normalised Difference Vegetation Index (NDVI) (Tucker, 1979), the Normalised Difference Water Index (NDWI) (Gao, 1996), the Soil Adjusted Vegetation Index (SAVI) (Huete, 1988), and the Vegetation Condition Index (VCI) (Kogan, 1995a) and the Temperature Condition Index (TCI) (Kogan, 1995b), which were later combined into the Vegetation Health Index (VHI) (Kogan, 1997).

262 Of these, the most well-established approach to agricultural drought monitoring is the NDVI. The NDVI's success derives from its exploitation of the 'red-edge' (the sharp increase in vegetation reflectance across the red and near-infrared regions of the electro-magnetic spectrum) to detect photosynthetically active plant material, from which plant stress can be inferred as the available moisture within the root zone is depleted (Wang et al., 2007; Chen 
et al., 2014; Ahmed et al., 2017; West et al., 2018). The NDVI is calculated using the nearinfrared (NIR) and visible red bands of a multispectral sensor (Equation 1).

269

$$
N D V I=\frac{N I R-R E D}{N I R+R E D} \quad(\text { Equation } 1)
$$

271

272 The logic for the use of the NDVI for agricultural drought monitoring is that soil moisture

273 plays a significant role in the sustained growth and healthiness of vegetation (Lavender \& Lavender, 2016). Should soil moisture drop below a certain threshold vegetation will respond by wilting, lowering the NDVI due to a weakening of the leaf tissue structure and reduced chlorophyll content.

277

One of the first applications of NDVI based drought monitoring used the NOAA (National

Oceanic \& Atmospheric Administration) AVHRR (Advanced Very High-Resolution

Radiometer). Launched in 1979, AVHRR enabled global scale vegetation mapping with a frequent revisit period (Tucker et al., 1983). This was followed by numerous studies which aimed to refine the AVHRR NDVI products by accounting for atmospheric conditions, cloud masking, scale, temporal lags, amongst other variables (Holben \& Fraser, 1984; Gatlin et al., 1984; Townshend et al., 1985; Holben, 1986; Loveland et al., 1991; Gutman, 1991; Eastman \& Fulk, 1993; Stone et al., 1994).

As of September 2018, the combined search of NDVI and drought using Scopus returns 983 scientific journal articles published since 1979. In a literature review of drought-related papers, the NDVI is featured as a key index in more than $30 \%$ of the 300 agricultural drought related papers reviewed (Figure 3). 




Figure 3: Treemap of monitoring approaches used in agricultural drought monitoring of the

NDVI-based drought monitoring has been conducted using a broad range of sensors over global, continental, regional and catchment scales (e.g. Park et al., 2004; Bayarjargal et al., 2006; Neigh et al., 2008; Rojas et al., 2011; Nicolai-Shaw et al., 2017). Drought assessment and monitoring using NDVI has been undertaken across North America (e.g. Hwang et al., 2017), South America (e.g. Sayago et al., 2017), Europe (e.g. Zribi et al., 2016), the Middle East (e.g. Pervez et al., 2014), Australia (e.g. Chen et al., 2014), Asia (e.g. Yu et al., 2003) and Africa (e.g. Funk \& Brown, 2006). Few studies using these sensors have successfully attempted to assess vegetation at finer more local scales, in particular when vegetation is highly heterogeneous or sparse, due to sensor spatial/spectral resolution limitations (e.g. 
More recently, studies using hyper-spatial/-spectral imagery (captured using very high spatial and spectral resolution satellites, aircraft, or ground-based/tram sensors) have also applied the NDVI to examine agricultural drought. For example, the Quickbird and RapidEye satellite sensors have shown great potential for high spatial resolution $(\sim 1 \mathrm{~m})$ assessment of drought impacts on vegetation (Garrity et al., 2013; Krofcheck et al., 2014), with results suggesting that vegetation dynamics closely reflect precipitation deficits at the field scale

314 (Laliberte et al., 2004). The majority of this high-/hyper-resolution research has been based in North America and Europe (e.g. Calaudio et al., 2006; Mänd et al., 2010; Coates et al., 2015), most likely due to the expense of obtaining such imagery, or the instalment of ground-based sensor systems, which cannot as easily be met in less developed regions.

NDVI based approaches do however have limitations. For example the NDVI only represents conditions on one specific date and does not show condition relative to longer term change, is easily influenced by soil brightness in areas of low-density vegetation (Huete, 1988; Jasinski, 1990), and, at the other end of the spectrum, is limited in its sensitivity in high density biomass environments (Mutanga et al., 2012; Galidaki et al., 2016). The Vegetation Health Index (VHI) (Kogan, 1997) was seen to offer notable improvements over standalone NDVI-based monitoring as it provides a representation of vegetation condition relative to long term change. The $\mathrm{VHI}$ is a weighted average of two sub-indices: the $\mathrm{VCl}$ (Kogan, 1995a) and the $\mathrm{TCl}$ (Kogan, 1995b)

$$
V C I=\frac{\left(N D V I-N D V I_{\min }\right) \times 100}{N D V I_{\max }-N D V I_{\min }}(\text { Equation } 2)
$$

$$
T C I=\frac{100\left(B T_{\max }-B T\right)}{B T_{\max }-B T_{\min }}(\text { Equation } 3)
$$




$$
V H I=\alpha \times V C I+(1-\alpha) \times T C I \text { (Equation 4) }
$$

333 Where $\mathrm{max} / \mathrm{min}$ represent the maximum and minimum values of that variable over the study period and BT is Brightness Temperature recorded from a thermal sensor. The $\mathrm{VCl}$ pixel-based normalisation minimises any spurious or short-term signals in the data and amplifies the long-term trend (Anyamba \& Tucker, 2012). Studies assessing the VCI have found that both NDVI anomalies and the $\mathrm{VCl}$ are correlated with rainfall deficits, but the $\mathrm{VCI}$ offers a more robust comparison of seasonal drought conditions (Liu \& Kogan, 1996). The $\mathrm{VCl}$ is commonly used, with results suggesting the index is effective in monitoring vegetation change and agricultural drought at continental scales (Jiao et al., 2016; Winkler et al., 2017).

The TCI makes use of thermal remote sensing technologies and measurements of LST. LST computed from thermal infrared bands, from sensors such as AVHRR and Landsat (Landsat 3 onwards), has been found to provide valuable information on surface moisture conditions (Gutman, 1990). As a result, efforts have been made to merge multispectral vegetation indices with measurements from thermal-equipped sensors, such as the Temperature Vegetation Drought Index (TVDI) (Sandholt et al., 2002) or the Vegetation Supply Water Index (VSWI) (Haboudane et al., 2004). Compared to NIR-based vegetation indices alone, temperature/brightness indices have been found to be more sensitive to soil water stress

350 (Wang et al., 2004).

352 By the time of its publication (1997) the VHI had successfully been used in research in parts of Asia, Europe, North America and Africa (Kogan, 1994a; 1994b; 1995a; 1995b). The VHI has been used in applications of drought management (e.g. San Miguel-Ayanz et al., 2000; 
Qu et al., 2019), in the development of more complex remote sensing monitoring approaches (e.g. Brown et al., 2008), and in vegetation health and crop studies (e.g. Rahman et al., 2009). The $\mathrm{VCl} / \mathrm{VHI}$ have also been used in combination with other indices such as the NDWI and Enhanced Vegetation Index (EVI) (Huete et al., 2002). The value of a multi-index approach is that different indices have been found to have differing sensitivities to factors including vegetation type/density/biomass and soil brightness (Prabhakara et al., 2015).

Given the main socio-economic impact of agricultural drought is the potential disequilibrium between the demand and supply of food/crops, being able to accurately monitor crop growth and productivity is of particular importance. A commonly used method to assess vegetation growth and productivity is to calculate gross primary productivity (GPP) (Figure 3). GPP represents the rate at which vegetation converts light into energy via photosynthesis (Gilabert et al., 2015). New sensors and analytical approaches have meant that traditional hydrological methods of calculating GPP have been revisited (Rossini et al., 2012). Many approaches now use satellite data in combination with models and other datasets (Song et al., 2013; Anav et al., 2015; Joiner et al., 2018). In the papers reviewed it was common for GPP to be based on the light-use efficiency (LUE) method of Monteith (1972) (Equation 5).

$$
\mathrm{GPP}=\operatorname{LUE} x F A P A R_{\text {chl }} x P A R_{\text {in }}(\text { Equation 5) }
$$
of PAR in absorbed by chlorophyll. The inclusion of remotely sensed data has largely been to

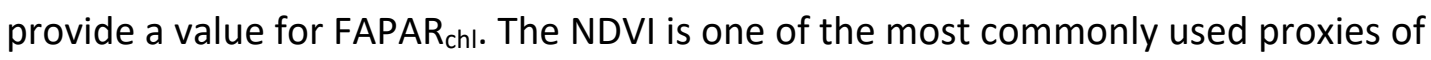


401

FAPAR $_{\text {chl }}$ (e.g. Zhang et al., 2009; Rossini et al., 2012; Joiner et al., 2018). Therefore, a revision to Equation 5 would be:

Where $\mathrm{VI}$ is the selected vegetation index to represent FAPAR $\mathrm{R}_{\mathrm{chl}}$ and $\mathrm{S}$ is a constant representing LUE (Sims et al., 2008). A range of satellites and sensors have been used to calculate the VI element of Equation 6 (Nightingale et al., 2007; Zhang et al., 2014; Dong et al., 2015; Bayat et al., 2018). This includes some hyper-resolution sensors (Krofcheck et al., 2014; Gitelson et al., 2018). Findings suggest that GPP is an important variable for monitoring drought and is more sensitive to non-typical dry conditions than traditional VIS such as the NDVI and EVI (Wagle et al., 2014). Sims et al. (2008) also note the non-linear relationship between GPP and LST under extreme drought conditions (compared to a linear relationship under normal conditions). This is likely due to the low values and highly variable nature of VIs under drought conditions (owing to poor quality/stressed vegetation or sparse coverage). GPP has also proved useful in the detection of irrigated/non-irrigated fields in droughty southern USA (Peng et al., 2013; Doughty et al., 2018).

Beyond calculation of GPP, some drought monitoring studies have further calculated the Water Use Efficiency (WUE) of crops (e.g. Lu \& Zhang, 2010; Ahmadi et al., 2019). WUE is defined as the ratio of leaf carbon uptake to water loss (Morison \& Morecroft, 2006). WUE can be calculated using Equation 7 
404 The volume of water used productively is taken as GPP, and the volume of water available

405 as evapotranspiration (Huang et al., 2015; Yang et al., 2016). MODIS GPP and

406

407

408

409

410

411

412

413

414

415

416

417

418

420

421

422

423

424

425

426 evapotranspiration products have been used to calculate WUE with results showing similar patterns to GPP under drought conditions. For example, Lu \& Zhuang (2010) show nonlinear trends between WUE and drought intensity; with WUE increasing under moderate conditions but decreasing sharply under severe drought.

While the development of multispectral and thermal indices from passive sensors has been of interest to the research community for some time, Kogan (1997) noted that while technology was advancing indices such as the NDVI and VHI, at the time, had not yet been ground-truthed or validated against traditional monitoring techniques. To an extent this is still true today, with issues around accuracy and uncertainty in remotely sensed data still a challenge (Liu et al., 2016). However, as demand has grown for continuous and reliable data, studies have examined the relationship between traditional approaches/ground measurements and remote sensing observations. Wang et al. (2007) found that MODIS derived NDVI at $16 \mathrm{~km}$ spatial resolution produced statistically significant correlations between NDVI and measured soil moisture. Gu et al. (2008) conducted similar analysis also using MODIS derived NDVI, finding that correlation between NDVI and measured soil moisture was dependent on landcover heterogeneity and soil type. Areas with homogenous vegetation cover and silt loams produced the highest correlations, while areas with heterogenous vegetation cover and loam soils produced the lowest correlations. The correlation between remote sensing and traditional meteorological/ground-based indices and data is significant in the field of remote sensing-based drought monitoring. Remote 
sensing indices offer a multi-scaled approach, and do not rely on site-based climatic datasets which are sparse in many parts of the world (Choi et al., 2013; Sur et al., 2015). As satellites are able to observe areas of the Earth where such ground-based datasets do not exist, effective drought monitoring and management can still take place.

\subsection{Microwave Remote Sensing Approaches}

Both active and passive sensors which record measurements in the microwave segment of the EMS have been applied in agricultural drought monitoring research. Active microwave sensors (radar/scatterometers) use backscatter strength to determine moisture conditions. Retrievals of soil moisture content from active microwave sensors can characterise key drought variables, including the intensity, frequency and spatial extent of soil moisture deficit. A key benefit of microwave sensors is they can provide continuous coverage over large geographic extents, and do not suffer the same limitations associated with light availability and cloud coverage as their multispectral counterparts.

However, active microwave sensors are limited in their ability to penetrate deep soil the sensor's wavelength. Longer wavelengths result in deeper penetration, with L-band sensors (around $1.4 \mathrm{GHz}$ ) offering the deepest measurements at around $1-5 \mathrm{~cm}$. Microwave sensors tend to have coarse spatial resolution (often kilometres, rather than metres)

447 resulting in studies having a global or continental scale; unlike passive sensors which have much finer spatial resolution allowing analysis to be undertaken at more local scales. This is often due to a trade-off between antenna size (affecting wavelength size and spatial resolution) and orbital geometry (which affects satellite revisit time) (Pan et al., 2017). In 
comparison to multispectral sensors, the number of microwave sensors in orbit is smaller,

452

453

454

455

456

457 as the former usually have a broader range of applications. Nonetheless, global coverage, long-term records and often short revisit times (daily/weekly) make microwave sensor derived soil moisture estimates valuable for drought monitoring and impact assessment over global, continental and regional scales.

The SMAP (Soil Moisture Active Passive) mission launched in 2015 was well positioned to revolutionise soil moisture remote sensing (Entekhabi et al., 2010). The goal was a product which merged high spatial resolution active radar and coarse-resolution, but highly sensitive, passive radiometer observations (Entekhabi et al., 2010; Das et al., 2014), to produce relatively high spatial $(3 \mathrm{~km}, 9 \mathrm{~km}$ and $36 \mathrm{~km})$ and temporal resolution (2-3 days) data products. Early SMAP data was assessed for accuracy and validity and satisfied all standards (Colliander et al., 2017). However, only 9 months into the mission the on-board radar equipment failed and was deemed unrepairable. However, there have been successful attempts to downscale and produce higher spatial resolution datasets using in-situ field observations and available active-passive algorithms (Das et al., 2018; Wei et al., 2019. There have also been attempts to compare and merge available SMAP products with observations from other active microwave sensors such as ASCAT (Advanced SCATterometer) (Kim et al., 2018), SMOS (Al-Yaari et al., 2017) and Sentinel-1 SAR data (Das et al., 2016) with varying results depending on local conditions. Despite the loss of the onboard radar, recent studies suggest SMAP products have potential for large scale agricultural drought monitoring. Eswar et al. (2018) compared SMAP estimates of soil moisture with modelled USDM (US Drought Monitor) and SPI data. Results indicated that SMAP data over 13-26 week intervals was able to accurately capture changing drought 
475

476

477

478

479

480

481

482

intensity levels. Bai et al. (2018) used SMAP estimates to calculate the Soil Water Deficit Index (SWDI) for mainland China and concluded that SMAP derived SWDI has good overall performance under drought conditions.

Launched in 2009, SMOS was the first mission to provide global measurements of L-band brightness temperature. Its microwave radiometer allows for remotely sensed estimation of soil moisture (and ocean salinity) with a spatial resolution of approximately $43-50 \mathrm{~km}$ and a revisit time of less than three days (Kerr et al., 2010). Like SMAP, studies using SMOS soil moisture retrievals suggest that the satellite is well suited to support the monitoring of agricultural drought, through both direct sensor observations or the data product's utility in calculating agricultural drought indices (e.g. Sánchez et al., 2016; Pablos et al., 2017; Tagesson et al., 2018). The SMOS mission is reported to be in excellent technical condition (Mecklenburg et al., 2016), so it is likely that the sensors role in agricultural drought monitoring will continue to grow.

The AMSR-E (Advanced Microwave Scanning Radiometer - Earth Observing System), also equipped with a passive microwave radiometer, has shown similar potential for effective drought monitoring (e.g. Rao et al., 2019). The AMSR-E observation record is made up of daily $25 \mathrm{~km}$ (resampled) soil moisture products from 2002-2011. AMSR-E historic products have been reanalysed to calculate various agricultural drought indices and results show that the data record has good potential for the representation of long-term drought events over large spatial scales (Champagne et al., 2011; Abelen et al., 2015; Draper \& Reichle, 2015; Zhang et al., 2017a; Liu et al., 2017). As with multispectral sensors, a range of active and passive microwave sensors, including those discussed above, have been evaluated against 
in-situ measurements with generally positive results, although this is dependent on analytical procedures and local characteristics (Al-Yaari et al., 2019; Zhang et al., 2019).

501

502

\subsection{Integrated Approaches to Drought Monitoring}

503 Zhang et al. (2017a) highlight the importance of a multi-/integrated index approach to 504 drought monitoring. Many studies use various remote sensing products to simultaneously 505 explore multiple drought types. Nicolai-Shaw et al. (2017) used GLEAM data as an additional 506 factor for agricultural drought monitoring, by exploiting the link between evaporation and

507 vegetation condition. The delay in the response of vegetation to peaks in evapotranspiration 508 was of particular interest; which the authors attribute to a potential limitation of GLEAM data - the underestimation of water availability in deeper soil horizons which supports plant 510 growth. In a similar study, Orth \& Destouni (2018) used various remote sensing data

511 products to assess water balance disequilibrium during droughts across mainland Europe. In particular, they focused on the relationship between various hydrological cycle stages, such as precipitation, evapotranspiration (GLEAM), vegetation condition (vegetation index based), and runoff. GLEAM data was incorporated to reveal patterns in evapotranspiration, which lagged significantly behind variations in runoff following drought onset in southern

516 Europe, suggesting that agricultural drought reduces runoff faster than it reduces

517 evapotranspiration.

Remotely sensed data products have also been used to calculate new integrated monitoring

520 indices designed to monitor various drought types. For example, Du et al. (2013) propose the Synthesized Drought Index (SDI) - a principal components product combining the Vegetation Condition Index (VCI) (Kogan 1995a), the Temperature Condition Index (TCI) 
523 (Kogan 1995b) and the $\mathrm{PCl}$. The uniqueness of the SDI is the integration of remote sensing

524 data products derived from MODIS and TRMM, allowing an integrated assessment of

525 precipitation deficit, soil moisture depletion and vegetation stress as drought propagates.

526 The integration of indices and different remote sensing derived data products is an

527 important development in effective drought monitoring across multiple drought 'types'.

528 This is highlighted by Zhang et al. (2017a) who found that shorter-term dry events are not

529 fully represented in many agricultural or hydrological drought indices; which are better

530 suited for longer-term drought monitoring. Therefore, there is a need to use some form of

531 meteorological index alongside these measures to fully examine drought propagation and

532 short-term meteorological droughts.

533

534 Even when monitoring a small number of drought-related variables it is important to

535 consider a range of comparable datasets from different sensor types (Hao et al., 2015). For

536 agricultural drought monitoring, Zhang et al. (2017a) show how different soil moisture

537 datasets and indices are correlated with different length accumulation periods of SPI data

538 (which represent different drought severity levels). Passive microwave remotely sensed

539 data from AMSR-E, in the form of the Soil Moisture Condition Index (SMCI) (Zhang \& Jia,

540 2013), correlated well with short-term SPI in regions with low vegetation cover, while

541 multispectral indices, such as the $\mathrm{VCl}$ and $\mathrm{TCl}$, were better correlated with 3-month SPI. The

542 use of multiple remotely sensed soil moisture products is clearly valuable in agricultural

543 drought monitoring as different indices and sensors have particular strengths and

544 weaknesses. However, the relationship will be highly dependent on the characteristics of

545 the land surface variables under observation, for example some vegetation parameters may

546 respond more slowly to drought onset than soil moisture at the same location due to 
resilient vegetation biophysical characteristics. Other local land surface characteristics will

548 also affect this relationship such as terrain and landcover (Zhang et al., 2017a).

550 The development of integrated indices combining traditional meteorological datasets and

551 remote sensing approaches has been of interest in drought monitoring research more

552 recently (Liu et al., 2016). The integration of local field measurements, such as those from

553 soil moisture probes, potentially offers a significant improvement over using remotely

554 sensed data alone. Even with recent advances in remote sensing, it is only possible to

555 measure the soil moisture content of the surface material $(1-5 \mathrm{~cm})$. This is problematic given

556 that crop roots are usually $10-20 \mathrm{~cm}$ deep, and consequently root zone soil moisture deficits

557 cannot be determined directly. This could be resolved by incorporating in-situ

558 measurements at deeper depths into drought monitoring techniques, alongside satellite

559 observations. The benefit of such approaches is that the spatial and temporal benefits of the

560 remote sensing approaches are retained, while localised data for soil moisture, precipitation

561 and other variables are also incorporated.

562

563 Brown et al. (2008) developed one of the first and most widely applied integrated drought

564 monitoring indices - VegDRI (Vegetation Drought Response Index). VegDRI was developed

565 to exploit the strengths of both remote sensing and climate-based drought monitoring

566 techniques. The remote sensing component provides spatial information about the

567 distribution and general condition of vegetation from NDVI data. VegDRI produces drought-

568 related vegetation stress/condition data at $1 \mathrm{~km}$ resolution which is updated weekly (Brown

569 et al., 2008). Initially VegDRI was compared against the USDM model and results suggested

570 that VegDRI offered significant advancements. As of 2015, VegDRI features as a part of the 
571 new USDM model to enhance the spatial resolution of modelled drought patterns (Hao \&

572 Singh, 2015). Since its development VegDRI has been used in the development of new

573 models (e.g. Tadesse et al., 2010) and to contribute to drought assessment at a national

574 scale (e.g. Wu et al., 2013). As new sensors are launched, and datasets developed, it is likely

575 that remotely sensed data will be incorporated into national scale models and early warning

576 systems in a similar way (Roy et al., 2014).

577

578 While the benefits of integrating field measurements and traditional meteorological indices

579 with remote sensing techniques are clear, many studies are still focusing on developing

580 solely remote sensing-based approaches. Since VegDRI (Brown et al., 2008) was published,

581 many remote sensing only based techniques have been proposed, such as the Temperature-

582 Vegetation-Soil Moisture Dryness Index (TVMDI) which utilises LST, soil moisture and NDVI

583 observations (Amani et al., 2017). This is likely due to newer and more advanced satellites

584 and sensors having been launched in the interim, such as Sentinel-2 and SMAP. As a result,

585 recent research has been characterised by the parallel development of both remote sensing

586 and integrated approaches (Figure 4).

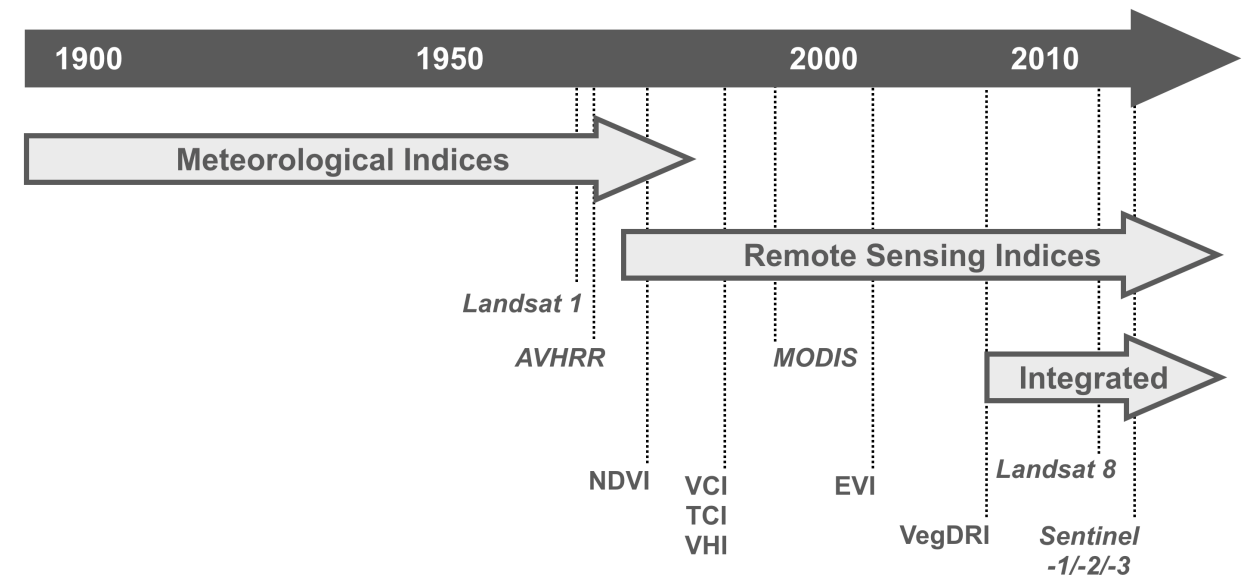

587

Figure 4: Key milestones and a chronological view of the development of agricultural

589 drought monitoring indices 
591 As evidenced previously, a review of the remote sensing literature relating to agricultural

592 drought monitoring found that the NDVI is by far the most commonly applied monitoring 593 method. This is significant given that since its development, many more sophisticated and

594 potentially more representative indices have been developed, including pure remote 595 sensing approaches, and integrative remote sensing and field-based indices. In relation to sensor type, passive sensors/approaches outnumber active in the papers reviewed. This is

597 likely due to a number of factors relating to data availability/resolution/timeliness, ease of application and interpretation, awareness of methods, and what is perceived as 'standard practice' (Bachmair et al., 2016).

600

601

\subsection{Streamflow Monitoring}

602

Agricultural droughts can trigger positive feedback loops in the hydrologic cycle (Teuling et al., 2005). Soil moisture will continue to be lost during a drought via evapotranspiration, which will be enhanced due to increased radiation and temperature (Van Loon, 2015). This loss will not be offset with precipitation, reducing the percolation and throughflow of water to recharge groundwater and streamflow (Ivanov et al., 2008). This triggers a hydrological

607 drought, characterised by a deficit in the supply of surface and subsurface water (Sheffield 608 \& Wood, 2011). Hydrological drought is often quantified by reduced

609 streamflow/groundwater and low levels in lakes and reservoirs (Tallaksen \& Van Lanen, 610 2004). Hydrological droughts occur over long time scales and socio-economic impacts can

611 be severe (Figure 2) (Isaak et al., 2012). 
In comparison with meteorological and agricultural drought, the development of remote

614 sensing-based approaches to hydrological drought has been more limited. In particular,

615 research into the role of remote sensing in providing estimates of river discharge has been

616 minimal due to the lack of sensors/satellites dedicated to this purpose (Lettenmaier et al.,

617 2015). Some studies have used basic fluvial geomorphological theory and supplementary in-

618 situ data (river flow gauges) to estimate discharge via remote sensing. Landsat and SAR

619 datasets have been used in this context to provide estimates of channel width to calculate

620 hydraulic geometry relationships (e.g. Smith et al., 1996; Gleason \& Smith, 2014; Gleason et

621 al., 2014). However, there are no studies to date which apply this within the context of

622 hydrological drought.

623 Through remote sensing technologies it has been possible however to monitor change in

624 Earth's total water storage in association with hydrological/groundwater drought. The

625 Gravity Recovery \& Climate Experiment (GRACE) (Tapley et al., 2004) mission launched in

6262002 was operated by NASA and the German Aerospace Center. The mission originally had a

627 lifespan of 5 years, however due to its successes, the mission was extended until 2017. The

628 GRACE mission consisted of two satellites in tandem orbit. On-board instruments measured

629 the distance between the satellites, which fluctuated at around $200 \mathrm{~km}$ as a result of Earth's

630 changing gravitational field. These measurements were used to produce monthly

631 representations of changes in the Earth's gravity field. The main drivers being the shifting

632 oceanic/atmospheric/terrestrial distribution of water within the hydrological cycle. GRACE

633 therefore observed terrestrial water storage (TWS) variations in all water storage locations

634 (soil moisture, surface water, and groundwater). GRACE was unique in its non-dependence 
635

636

637

638

639

640

641

642

643

644

645

646

647

648

649

650

651

652

653

654

655

656

657

on surface conditions and being able to provide measurements below the first five centimetres of the surface.

GRACE data has been successfully applied in numerous hydrological drought monitoring studies, for example in the analysis of drought event signatures and propagation (Hirschi et al., 2006; Yirdsaw et al., 2008; Thomas et al., 2014; Ma et al., 2017), examining regional differences in drought severity (Xavier et al., 2010; Frappart et al., 2013), and monitoring groundwater depletion (Rodell et al., 2009; Zhong et al., 2018). GRACE has also been used to calculate indices which can be applied in large scale hydrological drought monitoring, such as the Drought Severity Index (DSI) (Zhao et al., 2017), the Total Storage Deficit Index (TSDI) (Narasimhan \& Srinivasan, 2005; Yirdaw et al., 2008) and the Multivariate Standardised Drought Index (MSDI) (Forootan et al., 2019); most being applied in order to show spatio-temporal changes in drought severity (e.g. Voss et al., 2013; Zhao et al., 2015; Forootan et al., 2016). Recent work has also sought to incorporate GRACE data into complex hydrological and groundwater models (e.g. Schumacher et al., 2018) and in the USDM, GRACE was used to monitor hydrological/groundwater drought.

Under drought conditions GRACE data has been used alongside in-situ measurements and other sensors (Forootan et al., 2016), and assessed against climate models (Xia et al., 2016) and established hydrological drought indices. Results suggest that GRACE significantly improved our ability to monitor hydrological/groundwater drought over large spatial and temporal scales (Long et al., 2014; Thomas et al., 2017; Sun et al., 2017). For example, Forootan et al. (2019) used GRACE TWS data to assess the global distribution of hydrological drought events and their relationship with atmospheric/oceanic teleconnections. They found that droughts in the Middle East, America and South Asia have increased in intensity 
658

659

660

661

662

663

664

665

666

667

668

669

670

671

672

673

674

675

676

677

678

679

680

in recent years, and that in Asia and Australia hydrological drought events are largely associated with the El Niño Southern Oscillation (Forootan et al., 2019).

\subsection{Snow Monitoring}

Accurate monitoring of snow cover and depth is important for the characterization of hydrological droughts due to snow's role in ensuring constant water supply in many parts of the world (Shaban, 2009; Kumar et al., 2014). A lower than normal winter snowfall could lead to a hydrological drought through reduced streamflow supply later in the water year (AghaKouchak et al., 2015). As with other drought variables, long records and current observations of spatio-temporal consistent snow cover measurements, especially in mountainous upland areas, are not always readily available. Therefore, remote sensing plays an important role in providing these measurements.

Multispectral based snow monitoring approaches rely on snow's strong spectral reflectance/signature and discernibility from surrounding landcovers (Pepe et al., 2005; Dozier et al., 2009). Satellites and sensors such as AVHRR, MODIS and ENVISAT have been routinely used in multispectral-based snow cover assessments (Romanov et al., 2000; Pepe et al., 2005) and indices such as the Normalised Difference Snow Index (NDSI) have been proposed (Hall et al., 2002). Validation of multispectral snow cover datasets against in-situ measurements suggests high levels of accuracy, although this is heavily influenced by underlying and neighbouring landcovers (Hall \& Riggs, 2007; Simic et al., 2004). A significant limitation however of multispectral snow monitoring is the potential spectral signature confusion between snow cover and clouds, which can lead to notable snow cover overestimation (Wang et al., 2005). Alternatively microwave sensors, which are not limited 
by cloud cover, can provide estimates of both snow cover and depth (Durand et al., 2008).

682 However, the longer microwave wavelengths, and associated antenna size required to

683 achieve high spatial resolution data (or at least data comparable to that observed by

684 multispectral sensors), has been a technological limitation (Kongoli et al., 2012).

685 In specific relation to drought monitoring, studies have used remotely sensed snow

686

cover/depth estimates in numerous land surface/hydrological models in order to improve

687

streamflow estimates, and therefore monitor hydrological drought events (e.g. Dong et al.,

688

2007). Multispectral snow cover estimates have also been used alongside ancillary datasets,

689

such as soil moisture, in more general agricultural and hydrological drought monitoring

690 (Kumar et al., 2012)

691

692 8.0 Past Challenges \& Future Opportunities

693 The key challenge in the remote sensing of drought in the past has revolved around

694 resolution (spatial, spectral and temporal). Kogan (1997) noted that AVHRR data was used in

695 many of the index development studies that took place at the close of the $20^{\text {th }}$ Century.

696 AVHRR allowed for the development of drought monitoring indices based on a 1-month

697 data publication period. A month, however, could be considered too long a period to assess

698 variation in vegetation condition during a drought, as the water deficit related change in leaf

699 structure occurs between 3 and 7 days (Anyamba \& Tucker, 2012). Additionally, weather

700 patterns typically change at an even faster rate which can significantly affect the creeping

701 nature of drought onset and recession (Sen, 2015). Kogan (1997) therefore suggests that

702 one of the key limitations of remote sensing approaches at the time was that the monthly 
703

704

705

706

707

708

709

710

711

712

713

714

715

716

717

718

719

720

721

722

723

724

725

726

publication interval of data was inadequate. Studies conducted using MODIS and Landsat have also encountered temporal resolution limitations.

As well as challenges associated with temporal resolution, a recurring limitation of many remote sensing approaches has been the spatial and spectral resolution of sensors. In agricultural drought monitoring, for example, datasets derived using both active and passive sensors have encountered limitations associated with resolution (Becker, 2006; Davies et al., 2008; Rao et al., 2019). Often researchers have had to trade-off spatial and spectral resolution when selecting data products (Lavender \& Lavender, 2016; West et al., 2018). For example, when using multispectral sensors, it is common for either the spatial resolution not to be high enough to observe low density/dispersed vegetation, or the spectral resolution to be limited in its sensitivity to change in NIR reflection. These technological issues have limited the potential detection of changes in key environmental variables under drought conditions. Davies et al. (2016) attempted to use Landsat 8 derived NDVI (at 30m spatial resolution) to assess soil moisture recharge in semi-arid Rajasthan, India. While the results of this study were statistically inconclusive, they add to the body of evidence suggesting a role for remotely sensed NDVI products in providing proxy information for changes in moisture condition when sensors have appropriate spatial and spectral resolutions.

Following more recent technological advancements and the launch of new satellites/sensors there is renewed potential to address the limitations of previous studies with regard to resolution. The launch of the ESA (European Space Agency) Sentinel-2 multispectral imaging mission has provided a significant improvement in the spatial, spectral and temporal 
resolution of global coverage freely available multispectral imagery (Drusch et al., 2012). both satellites have been fully operational giving a revisit time of around 10 days at the equator and 2-3 days towards the poles (with the number of available images for analysis depending on latitude and cloud cover). Each Sentinel-2 satellite is equipped with a single MultiSpectral Instrument (MSI) with a ground-tracked swath of $290 \mathrm{~km}$ and 13 spectral bands (ranging from 10-60m spatial resolution), including four high spectral resolution bands positioned at the red-edge region of the EMS designed to provide spectrally precise measurements of vegetation condition and leaf chlorophyll content (Gitelson et al., 2005; Delegido et al., 2011; Clevers \& Gitelson, 2013; Frampton et al., 2013). Because of its enhanced resolution, initial studies have suggested that the mission has potential for considerable advances in the remote sensing of vegetation (Hill, 2013; Korhonen et al. 2017; Sadeghi et al., 2017; Clevers et al., 2017; Lambert et al., 2018; Vanino et al., 2018), which may in turn provide improvements in agricultural drought monitoring.

West et al. (2018) correlated NDVI derived from each NIR band from Sentinel-2 and the standard NIR band from Landsat 8 , against ground measured soil moisture in extreme drought conditions and sparse vegetation. While Sentinel-2 NDVI produced significant correlations (variation was found across the different NIR bands and spatial resolution), no significant results were found with NDVI derived from Landsat 8 . The spatial dispersion of vegetation may well explain the lack of significant results with Landsat 8 data due to the $30 \mathrm{~m}$ resolution being too coarse too detect the vegetation signal (West et al., 2018). The improved temporal resolution of Sentinel-2 was also noted in this study. As well as NDVI, GPP estimates derived from Sentinel-2 have been explored with promising results 
751 (Sakowska et al., 2016). Most research suggests a key role for Sentinel-2 in future drought

752 monitoring. A key research challenge remains however in assessing the relative importance

753 of spatial and spectral resolution in drought monitoring (Dotzler et al., 2015; Lepine et al.,

754 2016; Chemura et al., 2017).

755

756 As well as comparative studies, recent research has also sought to combine datasets from

757 Sentinel-2 and Landsat 8. The MSI on-board Sentinel-2 and the OLI (Operational Land

758 Imager) of Landsat 8 have partially overlapping spectral characteristics, and their differing

759 spatial resolutions can be addressed through resampling (e.g. Li et al., 2017). Therefore,

760 there is potential for data from the two to be integrated through data fusion or

761 transformation (e.g. Zhang et al., 2018). Data fusion of Sentinel-2 and Sentinel-3 has also

762

been explored (Korosov \& Pozdnyakov, 2016). Given that key drought-related variables such

763 as LST and NDVI can be derived from Sentinel-3's OCLI (Ocean Land and Colour Instrument)

764 and SLSTR (Sea and Land Surface Temperature Radiometer) sensors (Donlon et al., 2012), there may also be significant drought monitoring opportunities using combined Sentinel-2 and Sentinel-3 data that have yet to be fully explored (Guzinski \& Nieto, 2019).

767

Issues around spatial/spectral resolution may also be addressed with the continued rise in number of hyper-spatial/-spectral sensors being launched in the coming years. For example, the planned NASA HyspIRI (Hyperspectral InfraRed Imager), which will be equipped with $10 \mathrm{~nm}$ bands from the visible to short wave infrared segments of the EMS (see Lee et al., 2015), should be able to provide valuable measurements for agricultural drought-related monitoring. 
Beyond resolution-related limitations, a key challenge historically has been the shorter-term availability of remotely sensed data for inclusion in drought monitoring practices when compared to traditional in-situ measurements (Liu et al., 2016). For example, the SPI has a conventional requirement of a long-term precipitation record for calculation (Sen, 2015), which until fairly recently has not been available solely from remotely sensed data (e.g. the CHIRPS rainfall dataset). The availability of a long data record is what gives the Landsat series satellites and sensors a particular advantage over newer missions; having a 40-year record comprised of observations from 7 satellites (Roy et al., 2014). With the launch of Landsat 9 (currently scheduled for late 2020) this record will continue to expand allowing new opportunities for long term agricultural drought monitoring practices. The continuation of the Landsat record may also help in tackling limitations associated with Landsat 8's frequency of observation (e.g. West et al. 2018). Given the success of the GRACE mission, in hydrological drought monitoring and beyond, the remote sensing community also awaits measurements from the GRACE-FO (Follow On) mission which was successfully launched in May 2018 and will extend the data record of its predecessor.

As noted above, accurate estimate of river discharge from solely remotely sensed data is still a major ambition (Lettenmaier et al., 2015). The proposed 2020 launch of the ESA SWOT (Surface Water Ocean Topography) mission may well achieve this goal. SWOT is expected to provide estimates of water surface slope, elevation and width for large river systems globally (i.e. those with a minimum width of $100 \mathrm{~m}$ ). Research using synthetic SWOT observations of channel slope and elevation suggest great potential of the mission to reliably estimate river discharge (Andreadis et al., 2007; Biancamaria et al., 2011). While no 
research has been conducted relating SWOT to hydrological drought monitoring, the above studies suggest the sensor may have potential in this field.

800

801

As well as new sensors, opportunities for effective drought monitoring will continue to

802 expand with new approaches to 'blend' data products, such as the fusion of Landsat, Sentinel-2 and Sentinel-3 discussed above. A key example of a sensor blended data product

804 is the ESA CCI (Climate Change Initiative) SM (Soil Moisture) dataset. The CCI SM dataset combines various active and passive soil moisture datasets into three products: a merged ACTIVE and merged PASSIVE, and a COMBINED active and passive product (Dorigo et al., 2017). The current version of the dataset covers the period 1978-2016. The CCI SM dataset has been used in agricultural drought-related research (e.g. Chen et al., 2014; Sawada, 2018), with the authors noting the value of the long CCI SM data record. As the data continues to expand temporally and improve in accuracy, it is expected that its utility in the

811 field of drought monitoring will be core to examining long term soil moisture trends. Recent comparisons of CCI SM data and GLDAS (Global Land Data Assimilation) simulated soil moisture show that the two are significantly correlated; showing similar severity and spatial extents of drought events. However, the research concluded that the ESA CCI SM dataset is more effective in drought monitoring, except in highly vegetated areas (Liu et al., 2019); further demonstrating the high potential of this dataset.

818 As well as new sensors and data products, new applications of existing datasets and analytical platforms are becoming available as technology continues to advance. For example, recent work has seen SMAP data used to improve estimates of evapotranspiration

821 (Purdy et al., 2018). The utility of the Google EarthEngine in rapidly calculating 
evaporation/evapotranspiration for meteorological drought monitoring has already been

823 highlighted in this review. The platform allows for analysis of key remote sensing data products, including the full Landsat record from Landsat 4 onwards, Sentinel-2A, MODIS

825 (including Vl's, GPP estimates and thermal anomalies), and TRMM and GPM precipitation 826 estimates (Gorelick et al., 2017). However, the platform has still yet to be fully utilised for 827 wider/integrated drought monitoring approaches at a global scale.

With increased research on the effects of climate change and human activities, the role of anthropogenic influences on drought event propagation and termination is now becoming ever more apparent, suggesting that drought is not only a phenomenon induced by solely natural processes (Van Loon \& Van Lanen, 2013; Van Loon et al., 2016). Various methods to assess the role of human activity on drought have been proposed (Rangecroft et al., 2019; Van Loon et al., 2019), however no such research has yet considered the role of remote sensing and earth observation in assessing anthropogenic activity and the association with drought propagation/termination.

\subsection{Summary}

839 Since, 1970 there has been a fundamental shift in how we approach drought monitoring; moving away from traditional site-based measurements which are often limited in temporal

841 and spatial resolution to the deployment of remote sensing technologies. In 2005 Wilhite \&

842 Pulwarty noted four key issues in drought monitoring. These challenges are still relevant

843 today; however we suggest that the application of remote sensing has, and will continue to, help the research community address these: 
1. Spatial resolution and coverage: Remote sensing has significantly improved the coverage and spatial resolution of drought-related variables and has allowed for effective water management in data-poor regions (Sheffield et al., 2018). Sensors have large swaths and high temporal resolution, giving frequent global scale coverage. While in the past there have been limitations around spatial resolution (Brown et al., 2008; Davies et al., 2016), as technology advances this will become less of an issue in drought monitoring, particularly as advances are made in the development and deployment of hyper-resolution sensors.

2. Temporal frequency of observations: Due to the complex nature of drought events, in both their development and termination (Parry et al., 2016), regular observations of key variables are required. Through remote sensing a range of daily to weekly observations are available, such as (sub-)daily rainfall from GPM and weekly/biweekly vegetation condition indices from MODIS, Landsat and now Sentinel-2. Frequent observation, in combination with enhanced spatial coverage, of droughtrelated variables has provided data in what were traditionally data-sparse regions, particularly in the developing world.

3. A need for a range of drought indicators: There are a large number of remote sensing data products covering almost all phases of drought propagation, the exception being accurate and frequent observations of river discharge. The combined uses of these datasets to calculate drought monitoring indices has allowed for integrated studies monitoring drought propagation to be undertaken at scales previously unavailable to researchers (e.g. Nicolai-Shaw et al., 2017; Orth \& Destouni, 2018). 
4. A lack of understanding of extreme events: Wilhite \& Pulwarty (2005) noted this

870

871

872

873

874

875

876

877 In the field of drought monitoring the increasing detail, reliability and accuracy of remote

878

879

880

881

882

883

884

885

886

887

888

889

890

891

892 challenge in relation to the monitoring of both floods and droughts. Remote sensing technologies, through the wide range of sensors and data products, have allowed for greater understanding and better-informed decision making across a range of scales. For example, remote sensing is now commonly used to monitor irrigation systems in many very droughty and dry regions, allowing for scarce water resources to be effectively and efficiently managed to support crop growth (e.g. Vanino et al., 2018) sensing data products will enhance our capacity to forecast and monitor all forms of drought and its impacts at a range of spatial and temporal scales. As we move into the future and technology advances, we must extend the use of remote sensing in drought monitoring (Andela et al., 2013). This may be through the launch of new satellites/sensors or developing new approaches and methodologies to reanalyse existing data. We conclude this paper by thanking Remote Sensing of Environment for its role as a key platform for dissemination, and the research community for the advances in the field over the last 50 years, and now look forward to the continued application of remote sensing for effective, innovative and efficient drought monitoring solutions.

\section{Acknowledgements}

We would like to thank the three reviewers for their insightful and considered comments and suggestions on this review paper.

\section{References}


893 Abelen, S., Seitz, F., Abarca-del-Rio, R. \& Güntner, A. 2015. Droughts and floods in the La 894 Plata Basin in soil moisture and GRACE. Remote Sensing. Vol.7(6). 7324-7439.

895

896

AghaKouchak, A., Farahmand, A., Melton, F.S., Teixeria, J., Anderson, M.C., Wardlow, B.D. \& 897 Hain, C.R. 2015. Remote sensing of drought: Progress, challenges and opportunities, 898 Reviews of Geophysics, Vol.53(2), 452-480.

899

900

Ahmadi, B., Ahmadalipour, A., Tootle, G. \& Moradkhani, H. 2019. Remote sensing of water 901 use efficient and terrestrial drought recovery across the contiguous United States. Remote 902 Sensing. Vol.11(6), 731.

903

904 Ahmed, M., Else, B., Eklundh, L., Ardö, J., \& Seaquist, J. 2017. Dynamic response of NDVI to 905 soil moisture variations during different hydrological regimes in the Sahel region.

906 International Journal of Remote Sensing. Vol.38(19). 5408-5429.

907

908

Al-Yaari, A., Wigneron, J.-P., Dorigo, W., Colliander, A., Pellarin, T., Hahn, S., Mialon, A., 909 Richaume, P., Fernandez-Moran, R., Fan, L., Kerrm Y,H. \& Lannoy, G.De. 2019. Assessment and inter-comparison of recently developed/reprocessed microwave satellite soil moisture products using ISMN ground-based measurements. Remote Sensing of Environment.

912 Vol.224, 289-303.

913

914 Allen, R.G., Tasumi, M. \& Trezza, R. 2007. Satellite-based energy balance for mapping 915 evapotranspiration with internalized calibration (METRIC) - model. Journal of Irrigation \& Drainage Engineering. Vol.133(4). 380-394 
918 Alizadeh, M.R. \& Nikoo, M.R. 2018. A fusion-based methodology for meteorological drought 919 estimation using remote sensing data. Remote Sensing of Environment. Vol.211. 229-247. 920

921 Almazroui, M. 2011. Calibration of TRMM rainfall climatology over Saudi Arabia during 922 1998-2009. Atmospheric Research. Vol.99(3-4., 400-414.

923

924

Al-Yaari, A., Wigneron, J.-P., Kerr, Y., Rodriguez-Fernandez, N., O’Neill, P.E., Jackson, T.J., De 925 Lannoy, G.J.M., Al Bitar, A., Mialon, A., Richaume, P., Walker, J.P., Mahmoodi, A. \& Yueh, S. 926 2017. Evaluating soil moisture retrievals from ESA's SMOS and NASA's SMAP brightness temperature datasets. Remote Sensing of Environment. Vol.193 257-273.

928

929

Amani, M., Salehi, B., Mahdavi, S., Masjedi, A. \& Dehnavi, S. 2017. Temperature-vegetation930 soil moisture dryness index (TVMDI). Remote Sensing of Environment. Vol.197. 1-14.

931

932 Anav, A., Friedlingstein, P., Beer, C., Ciais, P., Harper, A., Jones, C., Murray-Tortarolo, G., 933 Papale, D., Parazoo, N.C., Peylin, P., Piao, S., Sitch, S., Viovy, B., Wiltshire, A. \& Zhao, M. 2015. Spatiotemporal patterns of terrestrial gross primary production: A review. Reviews of 935 Geophysics. Vol.53(3). 785-818.

936

937 Andela, N., Liu, Y.Y., van Dijk, A.I.J.M., de Jeu, R.A.M. \& McVicar, T.R. 2013. Global changes 938 in dryland vegetation dynamics (1988-2008) assessed by satellite remote sensing:

939 Comparing a new passive microwave vegetation density record with reflective greenness 940 data. Biogeosciences. Vol.10(10). 6657-6676. 
942 Andreadis, K.M., Clark, E.A., Lettenmaier, D.P. \& Alsdorf, D.E. 2007. Prospects for river

943 discharge and depth estimation through assimilation of swath-altimetry into a raster-based

944 hydrodynamics model. Geophysical Research Letters. Vol.34. L10403.

945

946 Anyamba, A. \& Tucker, C.J. 2012. Historical perspectives on AVHRR NDVI and vegetation

947 drought monitoring, in Wardlow, B.D., Anderson, M.C. \& Verdin, J.P. (eds.). Remote Sensing

948 of Drought: Innovative Monitoring Approaches. CRC Press: New York, United States of

949 America. pp. 23-51.

950

951 Assal, T.J., Anderson, P.J. \& Sibold, J. 2016. Spatial and temporal trends of drought effects in 952 a heterogeneous semi-arid forest ecosystem. Forest Ecology \& Management. Vol.365. 137953151.

954

955

Ault, T.R., Mankin, J.S., Cook, B.I., \& Smerdon, J.E. 2016. Relative impacts of mitigation 956 temperature and precipitation on $21^{\text {st }}$ Century megadrought in the American Southwest.

957 Science Advances. Vol.2(10). e1600873.

958

959

Bachmair, S., Stahl, K., Collins, K., Hannaford, J., Acreman, M., Svoboda, M., Knutson, C.,

960 Smith, K.H., Wall, N, Fuchs, B., Crossman, N.D. \& Overton, I.C. 2016. Drought indicators

961 revisited: the need for wider consideration of environment and society. Wiley

962 Interdisciplinary Reviews: Water. Vol.3(4). 
Baker, L.J., Hannaford, J., Chiverton, A. \& Svensson, C. 2016. From meteorological to

970 Vol.20(6). 3483-2505.

971

972 Baudoin, M.A., Vogel, C., Nortje, K., \& Naik, M. 2017. Living with drought in South Africa: 973 Lessons learnt from the recent El Niño drought period. International Journal of Disaster Risk 974 Reduction. Vol.2., 128-137.

975 comparative study of NOAA-AVHRR derived drought indices using change vector analysis. Remote Sensing of Environment. Vol.105. 9-22.

979

980

Bayat, B., van der Tol, C. \& Verhoef, W. 2018. Integrating satellite optical and thermal infrared observations for improving daily ecosystem functioning estimations during a drought episode. Remote Sensing of Environment. Vol.209. 375-394.

983

Bayissa, Y., Tadesse, T., Demisse, G. \& Shiferaw, A. 2017. Evaluation of satellite-based estimates and application to monitor meteorological drought for the Upper Blue Nile Basin, 
Becker, M.W. 2006. Potential for satellite remote sensing of groundwater. Ground Water.

989 Vol.44(2). 306-318.

990

991 Biancamaria, S., Durand, M., Andreadis, K.M., Bates, P.D., Boone, A., Mognard, M., 992 Rodríguez, E., Alsdorf, D.E., Lettenmaier, D.P. \& Clark, E.A. 2011. Assimilation of virtual wide 993 swath altimetry to improve Arctic river modelling. Remote Sensing of Environment.

994 Vol.115(2). 373-381.

995

996

Brown, J.F., Wardlow, B.D., Tadesse, T., Hayes, M.J. \& Reed, B.C. 2008. The Vegetation

997

Drought Response Index (VegDRI): A new integrated approach for monitoring drought stress 998 in vegetation. GIScience \& Remote Sensing. Vol.45(1). 16-46.

999

1000

Calaudio, H.C., Cheng, Y., Fuentes, D.A., Gamon, J.A., Luo, H., Oechel, W., Qui, H.L., Rahman, 1001

A.D. \& Sims, D.A. 2006. Monitoring drought effects on vegetation water content and luxes in 1002 chaparral with the 970nm water band index. Remote Sensing of Environment. Vol.103(3). 304-311.

1004

1005 Caracciolo, D., Francipane, A.,Viola, F., Valerio Noto, L. \& Deidda, R. 2018. Performances of 1006 GPM satellite precipitation over the two major Mediterranean islands. Atmospheric

1007 Research. Vol.213. 309-322.

1008

1009 Cattani, E., Merino, A., Guijarro, J.A. \& Levizzani, V. 2018. East Africa rainfall trends and 1010 variability 1983-2015 using three long term satellite products. Remote Sensing. Vol.10(6). 1011931. 
1013 Champagne, C., McNairn, H. \& Berg, A.A. 2011. Monitoring agricultural soil moisture extremes in Canada using passive microwave remote sensing. Remote Sensing of Environment. Vol.115(10). 2434-2444.

1016

1017 Chao, N., Wang, Z., Jiang, W., \& Chao, D. 2016. A quantitative approach for hydrological 1018 drought characterisation in Southwestern China using GRACE. Hydrogeology Journal. Vol.24(4). 892-903.

1020

1021

Chemura, A., Mutanga, O. \& Odindi, J. 2017. Empirical modeling of leaf chlorophyll content in coffee (Coffea Arabica) plantations with Sentinel-2 MSI data: Effects of spectral settings, spatial resolution, and crop canopy cover. IEEE Journal of Selected Topics in Applied Earth Observations and Remote Sensing. Vol.10(12). 5541-5550.

1025

Chen, T, De Jeu, R., Liu, Y.Y., Van der Werf, G.R., \& Dolman, A.J. 2014. Using satellite based soil moisture to quantify the water driven variability in NDVI: A case study over mainland Australia. Remote Sensing of Environment. Vol.140. 330-338.

1029

Choi, M., Jacobs, J.M., Anderson, M.C. \& Bosch, D.D. 2013. Evaluation of drought indices via remotely sensed data with hydrological variables. Journal of Hydrology. Vol.476. 265-273.

Clevers, J.G.P.W. \& Gitelson, A.A. 2013. Remote estimation of crop and grass chlorophyll and Nitrogen content using red-edge bands on Sentinel-2 and -3. International Journal of 
1037 Clevers, J.G.P.W., Kooistra, L. \& van den Brande, M.M.M. 2017. Using Sentinel-2 data for

retrieving LAI and lead and canopy chlorophyll content of a potato crop. Remote Sensing. Vol.9(5). 405.

1040

1041 Coates, A.R., Dennison, P.E., Roberts, D.A. \& Roth, K.L. 2015. Monitoring the impacts of 1042 severe drought on Southern California chaparral species using hyperspectral and thermal 1043 infrared imagery. Remote Sensing. Vol.7(11). 14276-14291.

1044

1045

Colliander, A., Jackson, T.J., Bindlish, R., Chan, S., Das, N., Kim, S.B., Cosh, M.H., Dunbar, R.S., 1046 Dang, L., Pashaian, L., Asanuma, J., Aida, K., Berg, A., Rowlandson, T., Bosch, D., Caldwell, T., 1047 Caylor, K., Goodrich, D., al Jassar, H., Lopez-Baeza, E., Martinez-Fermamdez, J., Gonzalez1048 Zamora, A., Livingston, S., McNairn, H., Pacheco, A., Moghaddam, M., Montzka, C., 1049 Notarnicola, C., Niedrist, G., Pellarin, T., Prueger, J., Pulliainen, J., Rautiainen, K., Ramos, J., 1050 Seyfried, P., Su, Z., Zeng, Y., van der Velde, R.,, Thibeault, M., Dorigo, W., Vreugdenhil, M., 1051 Walker, J.P., Wu, X., Monerris, A., O’Neil, P.E., Entekhabi, D., Njoku, E.G. \& Yueh, S. 2017. 1052 Validation of SMAP surface soil moisture products with core validation sites. Remote 1053 Sensing of Environment. Vol.191. 215-231.

1054

1055 Cook, B.I., Anchukaitis, K.J., Touchan, R., Meko, D.M. \& Cook, E.R. 2016. Spatiotemporal 1056 drought variability in the Mediterranean over the last 900 years. Journal of Geophysical 1057 Research. Vol. 121(5). 2060-2074. 

A., Bosh, D.D., Caldwell, T., Cosh, M.H., Collins, C.H., Lopez-Baeza, E., Moghaddam, M., Rowlandson, T., Starks, P.J., Thibeault, M., Walker, J.P., Wu, X., O’Neill, P.E., Yueh, S. \& Njoku, E.G. 2018. The SMAP mission combined active-passive soil moisture product at $9 \mathrm{~km}$ and 3km spatial resolutions. Remote Sensing of Environment. Vol.211. 204-217.

1064

Das, N.N., Entekhabi, D., Njoku, E.G., Shi, J.J.C., Johnson, J.T. \& Colliander, A. 2014. Tests of the SMAP combined radar and radiometer algorithm using airborne field campaign observations and simulated data. IEEE Transactions on Geoscience and Remote Sensing. Vol.52(4). 2018-2028.

1069

1070

Das, N.N., Entekhabi, D., Kim, S., Yueh, S. \& O’Neill, P. 2016. Combining SMAP and Sentinel data for high-resolution soil moisture product. IEEE International Geoscience and Remote Sensing Symposium (IGARSS). Beijing, China. 10-15 July 2016.

1073

Davies, T., Everard, M. \& Horswell, M. 2016. Community-based groundwater and ecosystem restoration in semi-arid North Rajasthan (3): Evidence from remote sensing. Ecosystem 1076 Services. Vol.21(A). 20-30.

1077

1078 Delegido, J., Verrelst, J., Alonsa, L. \& Moreno, J. 2011. Evaluation of Sentinel-2 red-edge 1079 bands for empirical estimation of green LAI and chlorophyll content. Sensors. Vol.11(7). 7063-7081. 
1082

1083

1084

1085

1086

1087

1088

1089

1090

1091

1092

1093

1094

1095

1096

1097

1098

1099

1100

1101

1102

1103

1104

1105

Dong, J., Walker, J.P., Houser, P.R. \& Sun, C. 2007. Scanning multichannel microwave radiometer snow water equivalent assimilation. Journal of Geophysical Research. Vol.112, D07106.

Dong, J., Xiao, X., Wagle, P., Zhang, G., Zhou, Y., Jin, C., Torn, M.S., Meyers, T.P., Suyker, A.E., Wang, J., Yan, H., Biradar, C. \& Moore III, B. 2015. Comparison of four EVI-based models for estimating gross primary production of maize and soybean croplands and tallgrass prairie under severe drought. Remote Sensing of Environment. Vol.162. 154-168.

Donlon, C., Berruit, B., Buongiorno, A., Ferreora, M,-H., Féménias, P., Frerick, J., Goryl, P., Klein, U., Laur, H., Mavrocordatos, C., Nieke, J., Rebhan, H., Seitz, B., Stroede, J. \& Sciarra, R. 2012. The Global Monitoring for Environment and Security (GMES) Sentinel-3 mission. Remote Sensing of Environment. Vol.120. 37-57.

Dorigo, W., Wagner, W., Albergel, C., Albrecht, F., Balsamo, G., Brocca, L., Chung, D., Ertl, M., Forkel, M., Gruber, A., Haas, E., Hamer, P.D., Hirschi, M., Ikonen, J., de Jeu, R., Kidd, R., Lahoz, W., Liu, Y.Y., Miralles, D., Mistelbauer, T., Nicoli-Shaw, N., Parinussa, R., Pratola, C., Reimer, C., van der Schalie, R., Seneviratne, S.I., Smolander, T. \& Lecomte, P. 2017. ESA CCI Soil Moisture for improved earth system understanding: State-of-the art and future directions. Remote Sensing of Environment. Vol.203. 185-215.

Dotzler, S., Hill, J., Buddenbaum, H. \& Stoffels, J. 2015. The potential of EnMAP and Sentinel2 data for detecting drought stress phenomena in deciduous forest communities. Remote Sensing. Vol.7(10). 14227-14258. 
1107 Doughty, R., Xiao, X., Wu, X., Zhang, Y., Bajgain, R., Zhou, Y., Qin, Y., Zou, Z., McCarthy, H., 1108 Friedman, J., Wagle, P., Basara, J., Steiner, J. 2018. Responses of gross primary production of 1109 grasslands and croplands under drought, pluvial, and irrigation conditions during 2010-2016, 1110 Oklahoma, USA. Agricultural Water Management. Vol.204. 47-59.

1112 Dozier, J., Green, R.O., Nolin, A.W. \& Painter, T.H. 2009. Interpretation of snow properties 1113 from imaging spectrometry. Remote Sensing of Environment. Vol.113(1), 25-37.

Draper, C. \& Reichle, R. 2015. The impact of near-surface soil moisture assimilation at

1116 subseasonal, seasonal, and inter-annual timescales. Hydrology \& Earth System Science.

1117 Vol.19. 4831-4844.

1118

1119 Drusch, M., Bello, D., Carlier, S., Colin, O., Fernandez, V., Gascon, F., Hoersch, B., Isola, C., 1120 Laberinti, P., Martimort, P., Meygret, A., Spoto, F., Sy, O., Marchese, F. \& Bargellini, P. 2012.

1121 Sentinel-2: ESA's optical high resolution mission for GMES Operational Services. Remote 1122 Sensing of Environment. Vol.120, 25-36.

1124 Du, L., Tian, Q., Yu, T., Meng, Q., Jancso, T., Udvardy, P. \& Huang, Y. 2013. A comprehensive 1125 drought monitoring method integrating MODIS and TRMM data. International Journal of Applied Earth Observation and Geoinformation. Vol.23. 245-253. 
Durand, M., Molotch, N.P. \& Margulis, S.A. 2008. Merging complementary remote sensing datasets in the context of snow water equivalent reconstruction. Remote Sensing of Environment. Vol.112(3), 1212-1225.

1131

1132

Dutra, E., Wetterhall, F., Giuseppe, F.D., Naumann, G., Barbosa, P., Vogt, J., Pozzi, W. \&

Pappenberger, F. 2014. Global meteorological drought - Part 1: Probabilistic monitoring.

Hydrology \& Earth System Sciences. Vol.18. 2857-2667.

1135

1136

Eastman, R.R. \& Fulk, M. 1993. Long sequence time series evaluation using standardised principal components. Photogrammetric Engineering \& Remote Sensing. Vol.59(6). 991-996.

1138

1139

Elhang, K.M. \& Zhang, W. 2018. Monitoring and assessment of drought focused on its impact on Sorghum Yield over Sudan by using meteorological drought indices for the period 2001-2011. Remote Sensing. Vol.10(8). 1231.

1142

1143 Entekhabi, D., Njoku, E.G., O’Neill, P., Kellogg, K., Crow, W., Edelstein, W., Entin, J., 1144 Goodman, S., Jackson, T., Johnson, J., Kimball, J., Peipmeier, J., Koster, R., McDonald, K., 1145 Moghaddam, M., Moran, S., Reichle, R., Shi, J., Spencer, M., Thurman, S., Tsang, L. \& Van 1146 Zyl, J. 2010. The Soil Moisture Active Passive (SMAP) mission. Proceedings of the IEEE. 1147 Vol.98(5). 704-716.

1149 Eswar, R., Das, N.N., Poulsen, C., Behrangi, A., Swigart, J., Svoboda, M., Entekhabi, D., Yueh, 1150 S., Doorn, B. \& Entin, J. 2018. SMAP soil moisture change as an indicator of drought 1151 conditions. Remote Sensing. Vol.10(5). 788. 
1153 Fisher, J.B., Melton, F., Middleton, E., Hain, C., Anderson, M., Allen, R., McCabe, M.F., Hook,

S., Baldocchi, D., Townsend, P.A., Kilic, A., Tu, K., Miralles, D.D., Perret, J., Lagouarde, J-P.,

Forootan, E., Khandu, J., Awange, J., Schumacher, M., Anyah, R., can Dijk, A.I.J.M. \& Kusche,

J. 2016. Quantifying the impacts of ENSO and IOD on rain gauge and remotely sensed precipitation products over Australia. Remote Sensing of Environment. Vol.172. 50-66.

Forootan, E., Khaki, M., Schumacher, M., Wulfmeyer, V., Mehrnegar, N., van Dijk, A.I.J.M., 2019. Understanding the global hydrological droughts of 2003-2016 and their relationships with teleconnections. Science of The Total Environment. Vol.650(2). 2587-2604.

Frampton, W.J., Dash, J., Watmough, G, \& Milton, E.J. 2013. Evaluating the capabilities of Sentinel-2 for quantitative estimation of biophysical variables in vegetation. ISPRS Journal of Photogrammetry and Remote Sensing. Vol.82. 83-92.

1173 Frappart, F., Seoane, L. \& Ramillien, G. 2013. Validation of GRACE derived terrestrial water storage from a regional approach over South America. Remote Sensing of Environment. 
1177 Funk, C.C. \& Brown, M.E. 2006. Intra-seasonal NDVI change projections in semi-arid Africa.

1178 Remote Sensing of Environment. Vol.101(2). 249-256.

1179

1180 Galidaki, G., Zianis, D., Gitas, I., Radoglou, K., Karathanassi, V., Tsakiri-Strati, M.,

1181 Woodhouse, I. \& Mallinis, G. 2016. Vegetation biomass estimation with remote sensing:

1182 Focus on forest and other wooded land over the Mediterranean ecosystem. International

1183 Journal of Remote Sensing. Vol.38(7). 1940-1966.

1184

1185

Gao, B. 1996. A Normalised Difference Water Index for remote sensing of vegetation liquid

water from space. Remote Sensing of Environment. Vol.58(3). 257-266.

1187

1188 Garrity, S.R., Allen, C.D., Brumby, S.P., Gangodagamage, C., McDowell, G. \& Cai, D.M. 2013.

1189 Quantifying tree mortality in a mixed species woodland using multitemporal high spatial

1190 resolution satellite imagery. Remote Sensing of Environment. Vol.129. 54-65.

1191

1192 Gatlin, J.A., Sullivan, R.J. \& Tucker, C.J. 1984. Considerations of and improvements to large 1193 scale vegetation monitoring. IEEE Transactions on Geoscience \& Remote Sensing. Vol.22(6). 1194 496-502.

1195

1196 Gilabert, M.A., Moreno, A., Maselli, F., Martínez, B., Chiesi, M., Sánchez-Ruiz, S., García-

1197 Haro, F.J., Pérez-Hoyos, A., Campos-Taberner, M., Pérez-Priego, O., Serrano-Ortiz, P. \&

1198 Carrara, A. 2015. Daily GPP estimates in Mediterranean ecosystems by combining remote 
sensing and meteorological data. ISPRS Journal of Photogrammetry and Remote Sensing.

1201

1202

Gitelson, A.A., Arkebaurer, T.J. \& Suyker, A.E. 2018. Convergence of daily light use efficiency 1203 in irrigated and rainfed C3 and C4 crops. Remote Sensing of Environment. Vol.217. 30-37.

1204

1205

Gitelson, A.A., Viña, A., Ciganda, V., Rundquist, D.C. \& Arkebauer, T.J. 2005. Remote

1206 estimation of canopy chlorophyll content in crops. Geophysical Research Letters. Vol.32(8).

1207 L08403.

1208

1209 Gleason, C.J. \& Smith, L.C. 2014. Toward global mapping of river discharge using satellite 1210 images and at-many-stations hydraulic geometry. Proceedings of the National Academy of

1211 Sciences of the United States of America. Vol.111. 4788-4791.

1212

1213 Gleason, C.J., Smith, L.C. \& Lee, J. 2014. Retrieval of river discharge solely from satellite 1214 imagery and at-many-stations hydraulic geometry: Sensitivity to river form and optimization parameters. Water Resources Research. Vol.50(2). 9604-9619.

1216

1217 Gorelick, N., Hancher, M., Dixon, M., Ilyushchenko, S., Thau, D. \& Moore, R. 2017. Google 1218 Earth Engine: Planetary scale analysis for everyone. Remote Sensing of Environment. Vol.202. 18-27.

1220 

MODIS NDVI and NDWI for vegetation drought monitoring using Oklahoma Mesonet soil moisture data. Geophysical Research Letters. Vol.35(22). L22401.

1224

1225

Gutman, G.G. 1990. Towards monitoring droughts from space. Journal of Climate. Vol.3(2). 282-295.

Gutman, G.G. 1991. Vegetation indices from AVHRR data: An update and future prospects.

Remote Sensing of Environment. Vol.35(2-3). 121-136.

1230

1231 Guzinski, R. \& Nieto, H. 2019. Evaluating the feasibility of using Sentinel-2 and Sentinel-3 satellites for high resolution evapotranspiration estimations. Remote Sensing of Environment. Vol.221, 157-172.

1234

Haboudane, D., Miller, J.R., Pattey, E., Zarco-Tejada, P.J. \& Strachan, I.B. 2004. Hyperspectral vegetation indices and novel algorithms for predicting green LAI of crop canopies: Modelling and validation in the context of precision agriculture. Remote Sensing of Environment. Vol.90(3). 337-352.

1239

1240 Hall, D.K., Riggs, G.A., Salomonson, V.V., DiGirolamo, N.E. \& Bayr, K.J. 2002. MODIS snow cover-products. Remote Sensing of Environment. Vol.83(1), 181-194. 
1246 Hao, C., Zhang, J. \& Yao, F. 2015. Combination of multi-sensor remote sensing data for

1247 drought monitoring over Southwest China. International Journal of Applied Earth

1248 Observation and Geoinformation. Vol.35. 270-283.

1249

1250 Hao, Z. \& Singh, V.P. 2015. Drought characterization from a multivariate perspective: A 1251 review. Journal of Hydrology. Vol.527. 668-678.

1252

1253 Hayes, M.J., Svoboda, M.D., Wardlow, B.D., Anderson, M.C. \& Kogan, F. 2012. Drought 1254 Monitoring, in Wardlow, B.D., Anderson, M.C. \& Verdin, J.P. (eds). Remote Sensing of 1255 Drought: Innovative Monitoring Approaches. CRC Press: New York.

1256

1257

Hill, M.J. 2013. Vegetation index suites as indicators of vegetation state in grassland and

1258 savanna: An analysis with simulated Sentinel-2 data for a North American transect. Remote Sensing of Environment. Vol.137. 94-111.

1260

1261 Hirschi, M., Seneviratne, S. \& Schär, C. 2006. Seasonal variations in terrestrial water storage 1262 for major midlatitude river basins. Journal of Hydrometeorology. Vol.7(1). 39-60.

1263

1264 Holben, B.N. 1986. Characteristics of maximum-value composite images from temporal 1265 AVHRR data. International Journal of Remote Sensing. Vol.7(11). 1471-1434

1267 Holben, B.N. \& Fraser, R.S. 1984. Red and near-infrared sensor response to off-nadir 1268 viewing. International Journal of Remote Sensing. Vol.5(1). 145-160. 
1270 Hou, A.Y., Kakar, R.K., Neeck, S., Azarbarzin, A.A., Kummerow, C.D., Kojima, M., Oki, R.,

1271 Nakamura, K. \& Iguchi, T. 2014. The Global Precipitation Measurement Mission. Bulletin of 1272 the American Meteorological Society. Vol.95. 701-722.

1273

1274 Huang, M., Piao, S., Sun, Y., Ciais, P., Cheng, L., Mao, J., Poulter, B., Shi, X., Zeng, Z. \& Wang, 1275 Y. 2015. Change in terrestrial ecosystem water use efficiency over the last three decades. 1276 Global Change Biology. Vol.21(6). 2366-2378.

1277

Huete, A.R. 1988. A soil-adjusted vegetation index (SAVI). Remote Sensing of Environment, Vol.25(3). 295-309.

1280

1281

Huete, A.R., Didan, K., Miura, T., Rodriguez, E.P., Gao, X. \& Ferreira, L.G. 2002. Overview of the radiometric and biophysical performance of the MODIS vegetation indices. Remote Sensing of Environment. Vol.83(1-2). 195-213.

1284

1285

Huffman, G.J., Adler, R.F., Arkin, P., Chang, A., Ferraro, R., Gruber, A., Janowiak, J., McNab,

A., Rudolf, B. \& Schneider, U. 1997. The global precipitation climatology project (GPCP)

1287 combined precipitation dataset. Bulletin of the American Meteorological Society. Vol.78(1).

$1288 \quad 5-20$.

1289

1290 Hwang, T., Gholizadeh, H., Sims, D.A., Novick, K.A., Brzostek, E.R., Phillips, R.P., Roman, D.T., 1291 Robeson, S.M. \& Rahman, A.F. 2017. Capturing species-level drought responses in a 
temperate deciduous forest using ratios of photochemical reflectance indices between sunlit and shaded canopies. Remote Sensing of Environment. Vol.199. 350-359.

1294

1295 IPCC 2014. Climate Change 2014: Synthesis Report. Contribution of Working Groups I, II, and 1296 III to the Fifth Assessment Report of the Intergovernmental Panel on Climate Change. IPCC:

1297 Geneva, Switzerland. pp. 151.

1298

1299

Isaak, D.J., Wollrab, S., Horan, D. \& Chandler, G. 2012. Climate change effects on stream and 1300 river temperatures across the Northwest US from 1980-2009 and implications for Salmonid 1301 fishes. Climatic Change. Vol.113(2). 449-524.

1302

1303

Islam, M.N. \& Uyeda, H. 2005. Comparison of TRMM 3B42 products with surface rainfall over Bangladesh. IGARSS 2005: Proceedings of IEEE International Geoscience and Remote Sensing Symposium. Vol.1-8. 4112-4115.

1306

Islam, M.N. \& Uyeda, H. 2007. Use of TRMM in determining the climatic characteristics of rainfall over Bangladesh. Remote Sensing of Environment. Vol.108(3). 264-276.

1309

1310 Ivanov, V.Y., Bras, R.L., \& Vivoni, E.R. 2008. Vegetation-hydrology dynamics in complex 1311 terrain of semi-arid areas: A mechanistic approach to modelling dynamic feedbacks. Water Resources Research. Vol.44(3). W03429. 
Jasinski, M.F. 1990. Sensitivity of the normalised difference vegetation index to subpixel canopy cover, soil albedo, and pixel scale. Remote Sensing of Environment. Vol.32(2-3). 169187.

1317

1318 Jiao, W., Zhang, L., Chang, Q., Fu, D., Cen, Y. \& Tong, Q. 2016. Evaluating and enhanced

Vegetation Condition Index ( $\mathrm{VCl}$ ) based on VIUPD for drought monitoring in the continental United States. Remote Sensing. Vol.8(3). 224.

1321

1322

Joiner, J., Yoshida, Y., Zhang, Y., Duveiller, G., Jung, M., Lyapustin, A., Wang, Y. \& Tucker, C.J. 2018. Estimation of terrestrial global gross primary production (GPP) with satellite datadriven models and eddy covariance flux data. Remote Sensing. Vol.10(9). 1346.

1325

Kerr, Y.H., Waldteufel, P., Wigneron, J-P., Delwart, S., Cabot, F., Boutin, J., Escorihuela, M-J., Font, J., Reul, N., Gruhier, C., Juglea, S.E., Drinkwater, M.R., Hahne, A., Martin-Neira, M. \& Mecklenburg, S. 2010. The SMOS Mission: New tool for monitoring key elements of the global water cycle. Proceedings of the IEEE. Vol.98(5). 666-687.

Kim, H., Parinussa, R., Konings, A.G., Wagner, W., Cosh, M.H., Lakshmi, V., Zohaib, M. \&

Choi, M. 2018. Global-scale assessment and combination of SMAP with ASCAT (active) and AMSR2 (passive) soil moisture products. Remote Sensing of Environment. Vol.204. 260-275. detections. Advanced Space Research. Vol.15(11). 91-100. 
Kogan, F.N. 1994b. NOAA plays leadership role in developing satellite technology for

1339 drought watch. Earth Observation Magazine. September issue. 18-21.

1340

1341 Kogan, F.N. 1995a. Droughts of the late 1980s in the United States derived from NOAA polar

1342 orbiting satellite data. Bulletin of the American Meteorological Society. Vol.76. 655-668.

1343

1344 Kogan, F.N. 1995b. AVHRR data for detection and analysis of vegetation stress.

1345 Meteorological Satellite Data Users Conference. Winchester, UK. 155-162.

1346

1347 Kogan, F.N. 1997. Global drought watch from space. Bulletin of the American Meteorological 1348 Society. Vol.78. 621-636.

1349

1350

Kongoli, C., Romanov, P. \& Ferraro, R. 2012. Snow cover monitoring from remote sensing

1351

satellites: Possibilities for drought assessment, in Wardlow, B.D., Anderson, M.C. \& Verdin,

1352

J.P. (eds.). Remote Sensing of Drought: Innovative Monitoring Approaches. CRC Press: New

York, United States of America. pp. 359-386..

1354

1355

Korhonen, L., Hadi, Packalen, P. \& Rautiainen, M. 2017. Comparison of Sentinel-2 and

Landsat- 8 in the estimation of boreal forest canopy cover and leaf area index. Remote

1357 Sensing of Environment. Vol.195. 259-274.

1358

1359

Korosov, A.A \& Pozdnyakov, D.V. 2016. Fusion of data from Sentinel-2/MSI and Sentinel-

1360

3/OLCI. Living Planet Symposium. Prague, Czech Republic. 9-13 May 2016.

1361 
Krofcheck, D.J., Eitel, J.U.H., Vierling, L.A., Schulthess, U., Hilton, T.M., Dettweiler-Robinson,

E., Pendleton, R. \& Litvak, M.E. 2014. Detecting mortality induced structural and functional changes in a piñon-juniper woodland using Landsat and RapidEye time series. Remote Sensing of Environment. Vol.151. 102-113.

1366

1367

Kumar, S.V., Peters-Lidard, C.D., Mocko, D., Reichle, R., Liu, Y., Arsenault, K.R., Xia, Y., Ek, M.,

Riggs, G., Livneh, B. \& Cosh, M. 2014. Assimilation of remotely sensed soil moisture and snow depth retrievals for drought estimation. Journal of Hydrometeorology. Vol.15(6), 24462469.

1371

1372

1373

Measuring Mission (TRMM) sensor package, Journal of Atmospheric and Oceanic

Technology. Vol.15(3). 809-817.

1375

1376

1377

1378 belt. Remote Sensing of Environment. Vol.216. 647-657.

1379

1380

1381

1382 in Southern New Mexico. Remote Sensing of Environment. Vol.93(1). 198-210.

Lavender, S. \& Lavender, A. 2016. Practical handbook of remote sensing. CRC Press: Florida, United States of America. 
1387 Lee, C.M., Cable, M.L., Hook, S.J., Green, R.O., Ustin, S.L., Mandl, D.J. \& Middleton, E.M. 1388 2015. An introduction to the NASA Hyperspectral InfraRed Imager (HyspIRI) mission and 1389 preparatory activities. Remote Sensing of Environment. Vol.167. 6-19.

1390

1391 Lepine, L.C., Ollinger, S.V., Ouimette, A.P. \& Martin, M.E. 2016. Examining spectral 1392 reflectance features related to foliar nitrogen in forests: Implications for broad-scale 1393 nitrogen mapping. Remote Sensing of Environment. Vol.173. 174-186.

1394

1395

Lettenmaier, D.P., Alsdorf, D., Dozier, J., Huffman, G.J., Pan, M. \& Wood, E.F. 2015. Inroads of remote sensing into hydrologic science during the WRR era. Water Resources Research. Vol.51(9). 7309-7342.

Li, Z., Zhang, H.K., Roy, D.P., Yan, L., Huang, H. \& Li, J. 2017. Landsat 15-m panchromaticassisted downscaling (LPAD) of the 30-m reflective wavelength bands to Sentinel-2 20-m resolution. Remote Sensing. Vol.9(7). 755.

1402

1403 Libertinio, A., Sharma, Lakshmi, V. \& Claps, P. 2016. A global assessment of the timing of 1404 extreme rainfall from TRMM and GPM for improving hydrologic design. Environmental Research Letters. Vol.11. 054003.

1406

1407 Liu, L., Liao, J., Chen, Z., Zhou, G., Su, Y., Xiang, Z., Wang, Z., Liu, X., Li, Y., Yu, J., Xiong, X. \& 1408 Shao, H. 2017. The microwave temperature vegetation drought index (MTVDI) based on 
1409 AMSR-E brightness temperatures for long term drought assessment across China (2003-

1410 2010). Remote Sensing of Environment. Vol.199. 302-320.

1411

1412 Liu, W.T. \& Kogan, F.N. 1996. Monitoring regional drought using the Vegetation Condition 1413 Index. International Journal of Remote Sensing. Vol.17(14). 2761-2782.

1414

1415 Liu, X., Zhu, X., Pan, Y., Li, S., Liu, Y. \& Ma, Y. 2016. Agricultural drought monitoring:

1416 Progress, challenges, and prospects. Journal of Geographical Sciences. Vol.26(6), 750-767.

1417

1418

1419

1420

Liu, Y., Liu, Y. \& Wang, W. 2019. Inter-comparison of satellite-retrieved and Global Land

Data Assimilation System-simulated soil moisture datasets for global drought analysis.

Remote Sensing of Environment. Vol.220, 1-18.

1421

1422

Lloyd-Hughes, B. 2014. The impracticality of a universal drought definition. Theory of

1423

Applied Climatology. Vol.117(3-4). 607-611.

1424

1425

Long, D., Shen, Y., Sun, A., Hong, Y., Longuevergne, L., Yang, Y., Li, B. \& Chen, L. 2014.

1426 Drought and flood monitoring for a large karst plateau in southwest China using extended GRACE data. Remote Sensing of Environment. Vol.155. 145-160.

1428

1429

Loveland, T.R., Merchant, J.W., Brown, J.F. \& Ohlen, D.O. 1991. Development of a land cover

characteristics database for the conterminous United States. Photogrammetric Engineering

1431

\& Remote Sensing. Vol.57(11). 1453-1463.

1432 
Lu, X. \& Zhuang, Q. 2010. Evaluating evapotranspiration and water-use efficiency of

1434 terrestrial ecosystems in the conterminous United States using MODIS and AmeriFlux data.

1435 Remote Sensing of Environment. Vol.114(9). 1924-1393.

1436

1437 Ma, S., Wu, Q., Wang, J. \& Zhang, S. 2017. Temporal evolution of regional drought detected 1438 from GRACE TWSA and CCI SM in Yunnan Province, China. Remote Sensing. Vol.9(11). 1124.

1440 Mänd, P., Hallik, L., Peñuelas, J., Nilson, T., Duce, P., Emmett, B.A., Beier, C., Estiarte, J.,

1441 Kalapos, T., Schmidt, I.K., Kovács-Lang, E., Preto, P., Tietema, A., Westerveld, J.W. \& Kull, O. 1442 2010. Responses of the reflectance indices PRI and NDVI to experimental warming and 1443 drought in European shrublands along a north-south climatic gradient. Remote Sensing of 1444 Environment. Vol.114(3). 626-636.

1445

1446 Martens, B., Miralles, D.G., Lievens, H., van der Schalie, R., de Jeu, R.A.M., Fermàndez-

1447 Prieto, D., Beck, H.E., Dorigo, W.A. \& Verhoest, N.E.C. 2017. GLEAM v3: Satellite-based land 1448 evaporation and root-zone soil moisture. Geoscientific Model Development. Vol.10. 190314491925.

1450

1451 Martínez-Fernández, J., González-Zamora, A., Sanchez, N., Gumuzzio, A. \& Herrero-Jiménez, 1452 C.M. 2016. Satellite soil moisture for agricultural drought monitoring: Assessment of the 1453 SMOS derived soil water deficit index. Remote Sensing of Environment. Vol.177. 277-286. 
1455

1456

1457

1458

1459

1460

1461

1462

1463

McKee, T.B., Doesken, N.J. \& Kleist, J. 1993. The relationship of drought frequency and duration to time scale. Preprints Eighth Conference on Applied Climatology. American Meteorological Society, Anaheim, California. 17-22 January 1993. 179-184.

Mecklenburg, S., Drusch, M., Kaleschke, L., Rodriguez-Fernandez, N., Reul, N., Kerr, Y., Font, J., Martin-Neira, M., Oliva, R., Daganzo-Eusebio, E., Grant, J.P., Sabia, R., Macelloni, G., Rautiainen, K., Fauste, J., de Rosnay, P., Munoz-Sabater, J., Verhoest, N., Lievens, H., Delwart, S., Crapolicchio, R., de la Fuente, A. \& Kornberg, M. 2016. ESA's Soil Moisture and Ocean Salinity Mission: From science to operational applications. Remote Sensing of Environment. Vol.180. 3-18.

Miralles, D.G., Holmes, T.R.H., De Jeu, R.A.M., Gash, J.H., Meesters, A.G.C.A. \& Dolman, A.J. 2011. Global land-surface evaporation estimated from satellite-based observations. Hydrology \& Earth System Science. Vol.15. 453-469.

Miralles, D.G., van den Berg, M.J., Gash, J.H., Parinussa, R.M., de Jeu, R.A.M., Beck, H.E., Holmes, T.R.H., Jiménez, C., Verhoest, N.E.C., Dorigo, W.A., Tueling, A.J. \& Dolman, A.J. 2014. El Niño-La Niña cycle and recent trends in continental evaporation. Nature Climate Change. Vol.4. 122-126.

Mishra, A., Vu, T., Veettil. A.V. \& Entekhabi, D. 2017. Drought monitoring with soil moisture active passive (SMAP) measurements. Journal of Hydrology. Vol.552. 620-632. 
Monteith, J.L. 1972. Solar radiation and productivity in tropical ecosystems. Journal of

1479 Applied Ecology. Vol.9(3). 747-766.

1480

1481 Morison, J.I.L. \& Moorecroft, M.D. 2006. Plant Growth \& Climate Change. Blackwell

1482 Publishing Ltd: Oxford.

1483

1484 Mutanga, O., Adam, E. \& Cho, M.A. 2012. High density biomass estimation for wetland

1485 vegetation using WorldView-2 imagery and ramdon forest regression algorithm.

1486 International Journal of Applied Earth Observation and Geoinformation. Vol.18. 399-406.

1487

1488 Myoung-Jin, U., Kim, Y. \& Park, D. 2018. Evaluation and modification of the drought severity 1489 index (DSI) in East Asia. Remote Sensing of Environment. Vol.209. 66-76.

1490

1491 Nagarajan, R. 2009. Drought Assessment. Springer: Berlin.

1492

1493 Narasimhan, B. \& Srinivasan, R. 2005. Development and evaluation of soil moisture deficit

1494 index (SMDI) and evapotranspiration deficit index (ETDI) for agricultural drought

1495 monitoring. Agricultural and Forest Meteorology. Vol.133(1-4). 69-88.

1496

1497 Neigh, C.S.R., Tucker, C.J. \& Townshend, J.R.G. 2008. North American vegetation dynamics 1498 observed with multi-resolution satellite data. Remote Sensing of Environment. Vol.112(4).

$1499 \quad 1749-1772$.

1500 
1501 Nicolai-Shaw, N., Zscheischler, J., Hirschi, M., Gudmundsson, L. \& Seneviratne, S.I. 2017. A

1502 drought event composite analysis using satellite remote sensing-based soil moisture.

1503 Remote Sensing of Environment. Vol.203. 216-225.

1504

1505 Nightingale, J.M., Coops, N.C., Waring, R.H. \& Hargrove, W.W. 2007. Comparison of MODIS

1506 gross primary production estimates for forests across the USA with those generated by a

1507 simple process model, 3-PGS. Remote Sensing of Environment. Vol.109(4). 500-509.

1508

1509 Orth, R. \& Destouni, G. 2018. Drought reduces blue-water fluxes more strongly than green-

1510 water fluxes in Europe. Nature Communications. Vol.9(1). 3602.

1511

1512

Pablos, M., Martínez-Fernández, J., Sánchez, N. \& González-Zamoria, A. 2017. Temporal and spatial comparison of agricultural drought indices from moderate resolution satellite soil moisture data over Northwest Spain. Remote Sensing. Vol.9(11). 1168.

1515

1516

Pal, J.S., Small, E.E. \& Eltahir, E.A.B. 2000. Simulation of regional scale water and energy

1517 budgets: Representation of sub-grid cloud and precipitation processes within Reg CM.

1518 Journal of Geophysical Research. Vol.105(D24). 29579-29594.

1519

1520 Palmer, W.C. 1965. Meteorological Drought. US Weather Bureau Research Paper. Vol.45. 58.

1521

1522 Pan, M., Yuan, X., Lu, H., li, X. \& Qin, G. 2017. Soil moisture estimation using active and passive remote sensing techniques, in Hong, Y., Zhang, Y. \& Khan, S.I. (eds.). Hydrologic 
Remote Sensing: Capacity Building for Sustainability and Resilience. CRC Press: New York,

1525 United States of America. pp. 37-57.

1526

1527 Park, S., Feddema, J.J. \& Egbert, S.L. 2004. Impacts of hydrological soil properties on drought 1528 detection with MODIS thermal data. Remote Sensing of Environment. Vol.89(1). 53-52.

1529

1530 Parry, S., Prudhomme, C., Wilby, R.L. \& Wood, P.J. 2016. Drought termination: Concept and 1531 Characterisation. Progress in Physical Geography. Vol.40(6). 743-767.

1532

1533

Peng, Y., Gitelson, A.A. \& Sakamoto, T. 2013 Remote estimation of gross primary

1534 productivity in crops using MODIS 259m data. Remote Sensing of Environment. Vol.128.

1535 186-196.

1536

1537

Pepe, M., Brivio, P.A., Rampini, A., Rota Nodari, F.R. \& Boschetti, M. 2005. Snow cover

1538 monitoring in Alpine regions using ENVISAT optical data. International Journal of Remote 1539 Sensing. Vol.26(21), 4661-4667.

1540

1541

Pervez, M.S., Budde, M. \& Rowland, J. 2014. Mapping irrigated areas in Afghanistan over the past decade using MODIS NDVI. Remote Sensing of Environment. Vol.149. 155-165.

1543

1544 Prabhakara, K., Hively, W.D. \& McCary, G.W. 2015. Evaluating the relationship between

1545 biomass, percent groundcover and remote sensing indices across six winter cover crop fields in Maryland, United States. International Journal of Applied Earth Observation and

1547 Geoinformation. Vol.39. 88-102. 
1549 Purdy, A.J., Fisher, J.B., Goulden, M.L., Colliander, A., Halverson, G., Tu, K. \& Famiglietti, J.S.

1550 2018. SMAP soil moisture improves global evapotranspiration. Remote Sensing of

1551 Environment. Vol.219. 1-14.

1552

1553 Qu, C., Hao, X. \& Qu, J.J. 2019. Monitoring extreme agricultural drought over the Horn of

1554 Africa (HOA) using remote sensing measurements. Remote Sensing. Vol.11(8), 902.

1555

1556 Rahman, A., Roytman, L., Krakauer, N.Y., Nizmuddin, M. \& Goldberg, M. 2009. Use of

1557 vegetation health data for estimation of Aus Rice Field in Bangladesh. Sensors. Vol.9(4).

$1558 \quad 2968-2975$.

1559

1560 Rajasekaren, E., Das, N.N., Poulsen, C., Behrangi, A., Swigart, J., Svoboda, M., Entekhabi, D.

1561 Yeh, S., Doorn, B. \& Entin, J. 2018. SMAP soil moisture change as an indicator of drought

1562 conditions. Remote Sensing. Vol.10(5). 788.

1563

1564 Rangecroft, S., Van Loon, A.F., Maureira, H., Verbist, K. \& Hannah, D.M. 2019. An

1565 observation-based method to quantify the human influence on hydrological drought:

1566 upstream-downstream comparison. Hydrological Sciences Journal. Vol.64(3), 276-287.

1567

1568

Rao, K., Anderegg, W.R., Sala, A., Martinez-Vilalta, J. \& Konings, A.G. 2019. Satellite-based

1569

vegetation optical depth as an indicator of drought-driven tree mortality. Remote Sensing of

1570

Environment. Vol.227, 125-136.

1571 
Rodell, M., Velicogna, I. \& Famiglietti, J.S. 2009. Satellite-based estimates of groundwater

1573 depletion in India. Nature. Vol.460. 999-1002.

1574

1575 Rojas, O., Vrieling, A. \& Rembold, F. 2011. Assessing drought probability for agricultural 1576 areas in Africa with coarse resolution remote sensing imagery. Remote Sensing of 1577 Environment. Vol.115(2). 343-352.

1578

1579 Romanov, P., Gutman, G. \& Csiszar, I. 2000. Automated montiroing of snow cover over

1580 North America with multispectral satellite data. Journal of Applied Meteorology and 1581 Climatology. Vol.39(11), 1866-1880.

1582

1583

Rossini, M., Cogliati, S., Meroni, M., Migliavacca, M., Galvagno, M., Busetto, L., Cremonese,

1584 E., Julitta, T., Siniscalco, C., Morra di Cella, U. \& Colombo, R. 2012. Remote sensing-based 1585 estimation of gross primary production in a subalpine grassland. Biogeosciences. Vol.9.

1586 2565-2584.

1587

1588

Roy, D.P., Wudler, M.A., Loveland, T.R., Woodcock, C.E., Allen, R.G., Helder, D., Irons, J.R., 1589 Johnson, D.M., Kennedy, R., Scambos, T.A., Schaaf, C.B., Schott, J.R., Sheng, Y., Vermote, 1590 E.F., Belward, A.S., Cohen, W.B., Gao, F., Hipple, J.D., Hostert, P., Huntington, J., Justice, 1591 C.O., Kilic, A.,, Kovalskyy, V., Lee, Z.P., Lymburner, L., Masek, J.G., McCorkel, J., Shuai, Y., 1592 Trezza, R., Vogelmann, J., Wynee, R.H. \& Zhu, Z. 2014. Landsat-8: Science and product vison 1593 for terrestrial global change research. Remote Sensing of Environment. Vol.145. 154-172. 
Sadeghi, M., Babaeian, E., Tuller, M. \& Jones, S.B. 2017. The Optical Trapezoid Model: A novel approach to remote sensing of soil moisture applied to Sentinel-2 and Landsat- 8 observations. Remote Sensing of Environment. Vol.198. 52-68.

1598

Sahoo, A.K., Sheffield. J., Pam, M. \& Wood, E.F. 2015. Evaluation of the Tropical Rainfall

Measuring Mission multi-satellite precipitation analysis (TMPA) for assessment of large scale meteorological drought. Remote Sensing of Environment. Vol.159. 181-193.

1602

1603 San Miguel Ayanz, J., Vogt, J., De Roo, A. \& Schmuck, G. 2000. Natural hazards monitoring: 1604 Forest fires, droughts and floods: The example of European pilot projects. Surveys in 1605 Geophysics. Vol.21(2-3). 291-305.

1606

Sánchez, N., González-Zamora, A., Piles, M. \& Martínez-Fernández, J. 2016. A New Soil

Moisture Agricultural Drought Index (SMADI) Integrating MODIS and SMOS Products: A Case of Study over the Iberian Peninsula. Remote Sensing. Vol.8(4). 287.

1611 Sandholt, I., Rasmussen, K. \& Andersen, J. 2002. A simple interpretation of the surface 1612 temperature/vegetation index space for assessment of surface moisture stress. Remote 1613 Sensing of Environment. Vol.79(2). 213-224.

Sakowska, K., Juszczak, R. \& Gianelle, D. 2016. Remote sensing of grassland biophysical 4612809. 
1620 dynamics using a newly developed ecohydrological land reanalysis. Remote Sensing.

1622

1623 Sayago, S., Ovando, G. \& Bocco, M. 2017. Landsat images and crop model for evaluating

1624 water stress of rainfed soybean. Remote Sensing of Environment. Vol.198. 30-39.

1625

1626

Sazib, N., Mladenova, I. \& Bolten, J. 2018. Leveraging the Google Earth Engine for drought assessment using global soil moisture data. Remote Sensing. Vol.10(8). 1265.

1628

1629 Schumacher, M., Forootan, E., van Dijk, A.I.J.M., Schmied, H.M., Crosbie, R.S., Kusche, J. \& 1630 Döll, P. 2018. Improving drought simulations within the Murray-Darling Basin by combining calibration/assimilation of GRACE data into the WaterGAP Global Hydrology Model. Remote Sensing of Environment. Vol.204. 212-228.

1633

Sen, Z. 2015. Applied drought modelling, predication and mitigation. Elsevier: Oxford.

1635

1636

Shaban, A. 2009. Indicators and aspects of hydrological drought in Lebanon. Water

Resources Management. Vol.23, 1875-1891.

1638

1639

Sheffield, J. \& Wood, E.F. 2011. Drought: Past problems and future scenarios. Earthscan:

1640 London. 
1643 Satellite remote sensing for water resources management: Potential for supporting sustainable development in data-poor regions. Water Resources Research. Vol.52(12), 97249758.

1646

1647 Simic, A., Fernandes, R., Brown, R., Romnov, P. \& Park, W. 2004. Validation of VEGETATION, 1648 MODIS and GOES C SSM/I snow-cover products over Canada based in surface snow depth observations. Hydrological Processes. Vol.18(6), 1089-1104.

1650

1651

Sims, D.A., Rahman, A.F., Cordova, V.D., El-Masri, B,Z., Baldocchi, D.D., Bolstad, P.V., Flanagan L.B., Goldstein, A.H., Hollinger, D.Y., Misson, L., Monson, R.K., Oechel, W.C., Schmid, H.P., Wofsy, S.C. \& Xu, L. 2008. A new model of gross primary productivity for North American ecosystems based solely on the enhanced vegetation index and land surface temperature from MODIS. Remote Sensing of Environment. Vol.112(4). 1633-1646.

1656

Smith, L.C., Isacks, B.L., Bloom, A.L. \& Murray, A.B. 1996. Estimation of discharge from three 1658 braided glacial rivers using synthetic aperture radar satellite imagery: Potential application to ungagged basins. Water Resources Research. Vol.32(7). 2021-2034.

1660

1661 Song, C., Dannenberg, M.P. \& Hwang, T. 2013. Optical remote sensing of terrestrial 1662 ecosystem primary productivity. Progress in Physical Geography: Earth and Environment. Vol.37(1). 834-854. 
Sun, A.Y., Scanlon, B.R., AghaKouchak, A. \& Zhang, Z. 2017. Using GRACE satellite gravimetry for assessing large-scale hydrologic extremes. Remote Sensing. Vol.9(12). 1287.

1671

1672 Sur, C., Hur, J., Kim, K., Choi, W. \& Choi, M. 2015. An evaluation of satellite-based drought

1673 indices on a regional scale. International Journal of Remote Sensing. Vol.36(22). 5593-5612.

1674

1675 Tadesse, T., Wardlow, B.D., Hayes, M.J., Svoboda, M.D. \& Brown, J.F. 2010. The Vegetation

Outlook (VegOut): A new method for predicting vegetation seasonal greenness. GIScience \& Remote Sensing. Vol.47(1). 25-52.

1678

1679 Tagesson, T., Horion, S., Nieto, H., Fornies, V.Z., González, G.M., Bulgin, C.E., Ghent, D. \& 1680 Fensholt, R. 2018. Disaggregation of SMOS soil moisture over West Africa using the 1681 Temperature and Vegetation Dryness Index based on SEVIRI land surface parameters. 1682 Remote Sensing of Environment. Vol.206. 424-441.

1683

1684 Tallaksen, L.M. \& Van Lanen, H.A.J. 2004. Hydrological drought: Processes and estimation 1685 methods for streamflow and groundwater. Elsevier Science: Netherlands. 

TMPA Version-7 legacy products over Mainland China at multiple spatiotemporal scales. Journal of Hydrology. Vol.533. 152-167.

1690 measurements of mass variability in the earth system. Science. Vol.305. 503-505.

Teuling, J., Uijlenhoet, R. \& Troch, P.A. 2005. On bimodality in warm season soil moisture observations. Geophysical Research Letters. Vol.32(13). 1-4.

1696

Thomas, B.F., Famiglietti, J.S., Landerer, F.W., Wiese, D.N., Molotch, N.P. \& Argus, D.F. 2017. GRACE groundwater drought index: Evaluation of California Central Valley groundwater drought. Remote Sensing of Environment. Vol.198. 384-392.

1700

1701 Thomas, A.C., Reager, J.T., Famiglietti, J.S. \& Rodell, M. 2014. A GRACE-based water storage 1702 deficit approach for hydrological drought characterization. Geophysical Research Letters. 1703 Vol.41(5). 1537-1545.

1704

1705 Toté, C., Patricio, D., Boogaard, H., van der Wijngaart, R., Tarnavsky, E. \& Funk, C. 2015.

1706 Evaluation of satellite rainfall estimates for drought and flood monitoring in Mozambique.

1707 Remote Sensing. Vol.7(2). 1758-1776.

1708 
1709 Townshend, J.R.G., Goff, T.E. \& Tucker, C.J. 1985. Multi-temporal dimensionality of images

1710 of Normalised Difference Vegetation Index at continental scales. IEEE Transactions on

1711 Geoscience \& Remote Sensing. Vol.23. 888-895.

1712

1713 Tucker, C.J. 1979. Red and photographic infrared combinations for monitoring vegetation.

1714 Remote Sensing of Environment. Vol.8(2). 127-150.

1715

1716 Tucker, C.J., Vanpraet, C.L., Boerwinkel, E. \& Gaston, A. 1983. Satellite remote sensing of

1717 total herbaceous biomass production in the Senegalese Sahel: 1980-1984. Remote Sensing 1718 of Environment. Vol.17(3). 461-474.

1719

1720 Ummenhofer, C.C., England, M.H., McIntosh, P.C., Meyers, G.A., Pook, M.J., Risbey, J.S.,

1721 Gupta, A.S., \& Taschetto, A.S. 2009. What causes Southeast Australia's worst droughts.

1722 Geophysical Research Letters. Vol.36(4). 1-5.

1723

1724 van Dijk, A.I.J.M., Schellekens, J., Yebra, M., Beck, H.E., Renzullo, L.J., Weerts, A. \& Donchyts,

1725

G. 2018. Global $5 \mathrm{~km}$ resolution estimates of secondary evaporation including irrigation

1726 through satellite data assimilation. Hydrology \& Earth System Science. Vol.22. 4959-4980.

1727

1728 Van Loon, A.F. 2015. Hydrological drought explained. WIREs Water. Vol.2. 359-392.

1729

1730 Van Loon, A.F. \& Laaha, G. 2015. Hydrological drought severity explained by climate and 1731 catchment characteristics. Journal of Hydrology. Vol.526. 3-14.

1732 
Van Loon, A.F., Gleeson, T., Clark, J., van Dijk, A.I.J.M., Stahl, K., Hannaford, J., Baldassarre,

1734 G.D., Tueling, A.J., Tallaksen, L.M., Uijlenhoet, R., Hannah, D.M., Sheffield, J., Svoboda, M.,

1735 Verbeiren, B., Wagener, T., Rangecroft, S., Wanders, N. \& Van Lanen, H.A.J. 2016. Drought in 1736 the Anthropocene. Nature Geoscience. Vol.9, 89-91.

1737

1738

Van Loon, A.F., Rangecroft, S., Coxon, G, Brena Naranjo, J.A., Van Ogtrop, F. \& Van Lanen,

H.A.J. 2019. Using paired catchments to quantify the human influence on hydrological

1740 droughts. Hydrological \& Earth System Sciences. Vol.23, 1725-1739.

1741

1742

Van Loon, A.F. \& Van Lanen, H.A.J. 2013. Making the distinction between water scarcity and drought using an observation-modelling framework. Water Resources Research. Vol.49, $1483-1502$.

1745

1746

Vanino, S., Nino, P., De Michele, C., Bolognwai, S.F., D’Urso, G., Di Bene, C., Penelli, B.,

Vuolo, F., Farina, R., Pulighe, G. \& Napoli, R. 2018. Capability of Sentinel-2 data for estimating maximum evapotranspiration and irrigation requirements for tomato crop in Central Italy. Remote Sensing of Environment. Vol.215. 452-470.

1750

1751 Vinukollu, R.K., Wood, E.F., Ferguson, C.R. \& Fisher, J.B. 2011. Global estimates of 1752 evapotranspiration for climate studies using multi-sensor remote sensing data: Evaluation of three process-based approaches. Remote Sensing of Environment. Vol.115(3). 801-823. 
management in the Tigris-Euphrates-Western Iran region. Water Resources Research.

1758 Vol.49(2). 904-914.

1759

1760 Wagle, P., Xiao, X., Torn, M.S., Cook, D.R., Matamala, R., Fischer, M.L., Jin, C., Dong, J. \&

1761 Birader, C. 2014. Sensitivity of vegetation indices and gross primary production of tallgrass

1762 prairie to severe drought. Remote Sensing of Environment. Vol.152. 1-14.

1763

1764 Wang, C., Qi, S., Niu, Z. Wang, J. 2004. Evaluating soil moisture status in China using the

1765 temperature-vegetation dryness index (TVDI). Canadian Journal of Remote Sensing.

1766 Vol.30(5). 671-679.

1767

1768

Wang, L., Sharp, M., Brown, R., Derksen, C. \& Rivard, B. 2005. Evaluation of spring snow

1769 covered area depeletion in the Canadian Arctic from NOAA snow charts, Remote Sensing of

1770 Environment. Vol.95(4), 453-463.

1771

1772 Wang, W., Estsen, M.W., Svoboda, M.D. \& Hafeez, M. 2016. Propagation of drought: From

1773 meteorological drought to agricultural and hydrological drought. Advances in Meteorology.

1774 Vol.2016. 1-5.

1775

1776 Wang, X., Hongjie, X., Guan, H. \& Zhou, X. 2007. Different responses of MODIS-derived NDVI 1777 to root-zone soil moisture in semi-arid and humid regions. Journal of Hydrology. Vol.340. $1778 \quad 12-24$.

1779 
1781 moisture fluctuation under extreme drought using Sentinel-2. Water. Vol.10. 838. DOI:

1782 https://doi.org/10.3390/w10070838.

1783

1784 Wei, Z., Meng, Y., Zhang, W., Peng, J. \& Meng, L. 2019. Downscaling SMAP soil moisture

1785

estimation with gradient boosting decision tree regression over the Tibetan Plateau. Remote

1786 Sensing of Environment. Vol.225, 30-44.

1787

1788 Winkler, K., Gessner, U. \& Hochschild, V. 2017. Identifying droughts affecting agriculture in

Africa based on remote sensing time series between 2000-2016: Rainfall anomalies and vegetation condition in context of ENSO. Remote Sensing. Vol.9(8). 831.

1791

1792

Wilhite, D.A. \& Glantz, M.H. 1985. Understanding the drought phenomenon: The role of definitions. Water International. Vol.10(3). 111-120.

1794

1795

Wilhite, D.A. \& Pulwarty, R.S. 2005. Drought and water crises: Lessons learned and the road 1796 ahead, in Wilhite, D.A. (eds.). Drought \& Water Crises: Science, Technology and Management Issues. CRC Press: Florida.

1798

1799 Wu, J., Zhou, L., Liu, M., Zhang, J., Leng, S. \& Dia, C.Y. 2013. Establishing and assessing the 1800 Integrated Surface Drought Index (IDSI) for agricultural drought monitoring in Mid-Eastern 
Wulder, M.A., Loveland, T.R., Roy, D.P., Crawford, C.J., Masek, J.G., Woodcock, C.E., Allen,

R.G., Anderson, M.C., Belward, A.S., Cohen, W.B., Dwyer, J., Erb, A., Gao, F., Griffiths, P., Helder, d., Hermosilla, T., Hipple, J,D., Hostert, P., Highes, J., Huntington, J., Johnson, D.M., Kennedy, R., Kilic, A., Li, Z., Lymburner, L., McCorkel, J., Pahlevan, N., Scambos, T.A., Schaaf, C., Schott, J.R., Sheng, Y., Storey, J., Vermote, E., Vogelmann, J., White, J.C., Wynne, R.H. \& Zhu, Z. 2019. Current status of Landsat program, science and applications. Remote Sensing of Environment. Vol.225, 127-147.

1811

Xavier, L., Becker, M., Cazenave, A., Longuvergne, L., Llovel, W. \& Rotunno Filho, O.C. 2010. Interannual variability in water storage over 2003-2008 in the Amazon Basin from GRACE space gravimetry, in situ river level and precipitation data. Remote Sensing of Environment. Vol.114(8). 1629-1637.

1816

Xia, L., Zhao, F., Mao, K., Yuan, Z., Zuo, Z. \& Xu, T. 2018. SPI-based analysis of drought changes over the past 60 years in China's major crop-growing areas. Remote Sensing. Vol.10(2). 171.

Xia, Z., Huete, A., Restrepo-Coupe, N., Ma, X., Devadas, R. \& Caparelli, G. 2016. Spatial partitioning and temporal evolution of Australia's total water storage under extreme hydroclimatic impacts. Remote Sensing of Environment. Vol.183. 43-52. monitoring drought events in southwest China. International Journal of Remote Sensing. Vol.39(10). 3186-3214. 
1829 Yang, Y., Guan, H., Batelaan, O., McVicar, T.R., Long, D., Piao, S., Liang, W., Liu, B., Jin, Z. \& 1830 Simmons, C.T. 2016. Contrasting responses of water use efficiency to drought across global 1831 terrestrial ecosystems. Nature: Scientific Reports. 6:23284.

Yirdsaw, S.Z., Snelgrove, K.R. \& Agboma, C.O. 2008. GRACE satellite observations of 1834 terrestrial moisture changes for drought characterization in the Canadian Prairie. Journal of Hydrology. Vol.356(1-2). 84-92.

1836

1837

Yu, F., Price, K.P., Ellis, J. \& Shi, P. 2003. Response of seasonal vegetation development to climatic variations in eastern central Asia. Remote Sensing of Environment. Vol.87(1). 42-54.

1839

1840

Zhang, A. \& Jia, G. 2013. Monitoring meteorological drought in semiarid regions using multisensor microwave remote sensing data. Remote Sensing of Environment. Vol.134. 12-23.

1842

Zhang, H.K., Roy, D.P., Yan, L., Zhongbin, L., Huang, H., Vermote, E., Skakun, S. \& Roger, J-C. 2018. Characterization of Sentinel-2A and Landsat- 8 top of atmosphere, surface, and nadir BRDF adjusted reflectance and NDVI differences. Remote Sensing of Environment. Vol.215. 482-494.

Zhang, L., Jiao, W., Zhang, H., Huang, C. \& Tong, Q. 2017a. Studying drought phenomena in the Continental United States in 2011 and 2012 using various drought indices. Remote Sensing of Environment. Vol.190. 96-106. 

satellite-derived estimate of the fraction of PAR absorbed by chlorophyll (FAPAR $\left.R_{\text {chl }}\right)$ improve predictions of light-use efficacy and ecosystem photosynthesis for a boreal aspen forest?. Remote Sensing of Environment. Vol.113(4). 880-888.

Zhang, X., Chen, N., Li, J., Chen, Z. \& Niyogi, D. 2017b. Multi-sensor integrated framework and index for agricultural drought monitoring. Remote Sensing of Environment. Vol.188. 141-163.

1860

Zhang, X., Moran, M.S., Zhao, X.Liu, S., Zhou, T., Ponce-Campos, G.E. \& Liu, F. 2014. Impact of prolonged drought on rainfall use efficiency using MODIS data across China in the early $21^{\text {st }}$ Century. Remote Sensing of Environment. Vol.150. 188-197.

1864

1865

Zhang, R., Kim, S. \& Sharma, A. 2019. A comprehensive validation of the SMAP Enhanced Level-3 Soil Moisture product using ground measurements over varied climates and landscapes. Remote Sensing of Environment. Vol.223, 82-94.

Zhao, M., Velicogna, I. \& Kimball, J.S. 2017. A global gridded dataset of GRACE drought severity index for 2002-2014: Comparison with PDSI and SPEI and a case study of the

1871 Australia millennium drought. Journal of Hydrometeorology. Vol.18(8). 2117-2129.

1873 Zhao, Q., Chen, Q., Jiao, M., Wu, P., Gao, X., Ma, M. \& Hong, Y. 2018. The temporal-spatial characteristics of drought in the Loess Plateau using the remote-sensed TRMM precipitation data from 1998 to 2014. Remote Sensing. Vol.10(6). 838. 
1877 Zhao., Q., Wu, W. \& Wu, Y. 2015. Variations in China's terrestrial water storage over the past decade using GRACE data. Geodesy and Geodynamic. Vol.6(3). 187-193.

1879

1880 Zhong, Y., Zhang, M., Feng, W., Zhang, Z., Shen, Y. \& Wu, D. 2018. Groundwater depletion in 1881 the West Liaohe River Basin, China and its implications revealed by GRACE and in situ 1882 measurements. Remote Sensing. Vol.10(4). 493.

1883

1884 Zribi, M., Dribi, G., Amri, R. \& Lili-Chananne, Z. 2016. Analysis of the effects of drought on 1885 vegetation cover in a Mediterranean region through the use of SPOT-VGT and TERRAMODIS long time series. Remote Sensing. Vol.8(12). 992.

1887

1888

\section{Figure Captions}

1889 Figure 1: Number of papers relating to drought (in both paper titles and keywords) in 1890 Remote Sensing of Environment and Web of Science since 1982. Search terms included 1891 various versions of 'Drought' and 'Remote Sensing'.

1893 Figure 2: Different types of drought, their interactions and associated impacts (Adapted 1894 from Van Loon, 2015)

1895

Figure 3: Treemap of monitoring approaches used in agricultural drought monitoring of the papers reviewed. Papers were sourced from a range of journals including Remote Sensing of Environment, Remote Sensing, and the International Journal of Remote Sensing. 
1900 Figure 4: Key milestones and a chronological view of the development of agricultural 1901 drought monitoring indices 